\title{
The Montagne Noire migmatitic dome emplacement (French Massif Central): New insights from petrofabric and AMS studies
}

\author{
Nicolas CHARLES*, Michel FAURE and Yan CHEN
}

Université d’Orléans - CNRS/INSU - Université François-Rabelais de Tours

Institut des Sciences de la Terre d'Orléans (ISTO)

1A rue de la Férollerie

45100 Orléans cedex 2

France

*Corresponding author: nicolas.charles@univ-orleans.fr

\begin{abstract}
In the southern French Massif Central, the Montagne Noire axial zone is a NE-SW elongated granite-migmatite dome emplaced within Visean south-verging recumbent folds and intruded by syn- to late-migmatization granitoids. The tectonic setting of this dome is still disputed, thus several models have been proposed. In order to better understand the emplacement mechanism of this dome, petrofabric and Anisotropy of Magnetic Susceptibility (AMS) studies have been carried out. In the granites and migmatites that form the dome core, magmatic texture and to a lesser extent weak solid-state texture are dominant. As a paramagnetic mineral, biotite is the main carrier of the magnetic susceptibility. On the basis of 135 AMS sites, the magnetic fabrics appear as independent of the lithology but related to the dome architecture. Coupling our results with previous structural and geochronological studies, allows us to propose a new emplacement model. Between 340-325 Ma, the Palaeozoic series underwent a compressional deformation represented by nappes and recumbent folds involving the thermal event leading to partial melting. Until 325-310 Ma, the dome emplacement was assisted by diapiric processes. An extensional event took place at \%300 Ma, after the emplacement of the late to post-migmatitic granitic plutons. In the northeast side of the dome, a brittle normal-dextral faulting controlled the opening of the Graissessac coal-basin.
\end{abstract}

Keywords: migmatitic dome, AMS, petrofabric, diapirism, Variscan belt, Montagne Noire 


\section{Introduction}

Since Eskola (1949), first recognized their existence, gneiss and migmatite domes have been frequently observed in orogenic belts but their tectonic settings remain disputed (e.g. Whitney et al., 2004 and enclosed references). Nevertheless, a good understanding of the dome dynamics of such a migmatite dome can help structural geologists to understand the regional geodynamics of a large part of the orogen. Several models have been proposed to account for emplacement mechanisms, namely: i) diapirism, ii) anticlinal stacking, iii) post-thickening extension, or a combination of these processes (e.g. Ramberg, 1967; Ramberg, 1980; Davis and Coney, 1979; Wernicke and Burchfield, 1982; Whitney et al., 2004).

In the French Variscan Belt, gneiss and migmatites that develop in the Massif Central, the southern part of the Massif Armoricain or the Pyrénées are variously analyzed and interpreted in terms of their bulk architecture, kinematics, age, emplacement process, and tectonic setting (e.g. Schuiling, 1960; Zwart, 1986; Vissers, 1992; Carreras and Capella, 1994; Brown, 2005; Mezger, in press). Among these structures, the Montagne Noire axial zone (Fig. 1) is one of the most typical metamorphic domes recognized in the Variscan Belt since Gèze (1949), but its emplacement mechanism and tectonic significance remain highly controversial. Numerous studies have been carried out since more than half a century in order to decipher the doming processes and the relationships with the regional tectonics (e.g. Gèze, 1949; Schuiling, 1960; Nicolas et al., 1977; Beaud, 1985; Faure and Cottereau, 1988; Echtler and Malavieille, 1990; Maluski et al., 1991; Van Den Driessche and Brun, 1992; Brun and Van Den Driessche, 1994; Mattauer et al., 1996; Brunel and Lansigu, 1997; Matte et al., 1998; Demange et al. 1999; Soula et al., 2001 and enclosed references; see Discussion section below for details).

Furthermore, several weak points have hampered the validity of these models. Firstly, the timing of the polyphase deformation has long been poorly constrained by the lack of accurate geochronological data (Hamet and Allègre, 1976; Maluski et al., 1991). However, recently, more and more geochronological data became available for the various generations of granitoids that form the centre of the Montagne Noire axial zone (Cocherie et al., 2003; Roger et al., 2004; Bé Mézème, 2005; Charles et al., 2008). Secondly, mainly due to outcrop quality, most of studies focussed on the eastern termination and southern flank of the dome where extensional deformation overprints older features. A few studies take into account the entire domal structure (see Soula et al., 2001 for extensive references). Lastly, in spite of some petrological works (Bard and Rambelonson, 1973; Demange, 1982; Bogdanoff et al., 1984), the structural features of the migmatites and granites which form the main part of the 
axial zone have never been considered in any previous models. Indeed, in the field, even if the fabric of these plutonic rocks can be rarely identified, generally the planar and linear structures are not easily recognized. Therefore, the structure of the core of the Montagne Noire axial zone must be investigated by using petrofabric tools such as universal stage or texture goniometer. However, faster and more efficient ones, such as the systematic use of the Anisotropy of Magnetic Susceptibility (AMS), can substitute these time-consuming methods. AMS studies in plutonic rocks are quite common (e.g. Bouchez, 2000; Rochette et al., 1992; Benn et al., 1998; Asrat et al., 2003; Talbot et al., 2003, 2005a, 2005b). Conversely, the AMS approach for fabric analysis in migmatites and anatectic rocks is rare (Ferré et al., 2003). Furthermore, in order to get a meaningful geological significance, the AMS study requires and have to be completed by: i) a careful magnetic mineralogy investigation to identify the bearer of the AMS (e.g. Borradaile, 1988; Rochette et al., 1992; Borradaile and Henry 1997), and also ii) a microscopic observation of the rock forming mineral preferred orientation to define the rheological state experienced by the rock when it acquired its magnetic fabric (e.g. Gapais and Barbarin, 1986; Hibbard, 1987; Paterson et al., 1989; Simpson and Wintsch, 1989).

In the following, petrofabric and AMS analyses of the migmatites and granitoids that constitute the core of the Montagne Noire axial zone are provided. The combination of these new results with previous structural and geochronological data allow us to re-evaluate the existing models, to discuss the emplacement mechanism, and to propose a new evolution model of this southern segment of the French Variscan Belt.

Fig.1

\section{The Montagne Noire in the Southern French Massif Central}

In spite of some controversial points, most of authors agree on the bulk architecture of the Variscan French Massif Central. It is widely acknowledged that the French Massif Central consists of a stack of ductile and synmetamorphic nappes edificated during Devonian and Carboniferous times (e.g. Ledru et al., 1989; Faure et al., 1997, 2005 and enclosed references). Conversely to the northern areas, the eo-Variscan (Devonian) events are lacking in the southernmost part of the French Massif Central, or Montagne Noire. This area underwent its first deformation during the Middle Carboniferous (Visean to early Namurian) times. Since Gèze (1949) and Arthaud (1970), the Montagne Noire is classically subdivided from north to south in northern, axial and southern zones (Figs. 1 and 2). The Palaeozoic series consist of sedimentary rocks ranging from Early Cambrian to Silurian and from Early Cambrian to Visean in the northern and southern zones, respectively. These series are involved in large-scale, south-verging recumbent folds (Fig. 2) and show a low to moderate 
metamorphic grade. Emplacement of the recumbent folds is stratigraphically dated of Late Visean to Namurian by the syntectonic foreland sedimentary basin in which they emplace (Engel et al., 1980; Feist and Galtier, 1985).

The axial zone consists of metamorphic rocks, migmatites, and plutonic rocks globally arranged in a bulk domal shape. To the west, SW of Mazamet, the dome shape is well delineated by the geometry of the micaschist-gneiss contact. Conversely, to the east, the tight Rosis micaschist synform subdivides the axial zone dome into the Espinouse and Caroux sub-domes (Figs. 1 and 2). Lithological and structural details of the axial zone will be provided in the next section. Moreover, the northeastern part of the axial zone is bounded by a brittle normal fault, called the Graissessac fault. During the Late Carboniferous (Stephanian), conglomerate, coarse grained sandstone, pelite and coal measures filled the Graissessac basin opened by the normal-dextral motion of the Graissessac fault (Bogdanoff et al., 1984; Echtler and Malavieille, 1990). The Graissessac brittle fault must not be confused with the ductile Monts-de-Lacaune fault (MLF) that separates migmatites and granites from high temperature-low pressure micaschist and marbles from south to north, respectively (Fig. 2), even if a relation between the two faults might be considered. The MLF is a ductile structure characterized by a north dipping foliation and a mineral lineation inclined of nearly $45^{\circ}$ to the east. Subsequently, the MLF acted as a normal fault with a dextral wrench component. East of Graissessac, Early Permian (Autunian) continental rocks, characterized by red sandstone and mudstone that form the Lodève basin, unconformably overly the Late Carboniferous terrigeneous rocks. The southwestern termination of the axial zone, or Nore massif, is separated from the main part of the dome by the Eocene, northdirected, reverse fault of Mazamet (Fig. 1). This structure, related to the Pyrenean orogeny, does not overprint significantly the Variscan architecture of the Montagne Noire axial zone.

In spite of the controversy on the Montagne Noire dome emplacement, there is a large consensus for the relative chronology of the tectonic events: i) recumbent folding and thrusting, ii) doming, iii) post-migmatitic granitoid emplacement, and iv) infill of the Graissessac coal basin during a generalised extensional event.

Fig.2

\section{Geological outline of the Montagne Noire axial zone}

\subsection{Lithology and age of the constitutive rocks}

As stated above, the Montagne Noire axial zone is a NE-SW elongated granitemigmatite dome. Several rock types can be recognized. Augen orthogneiss yield zircon U-Pb ages of $471 \pm 4 \mathrm{Ma}, 456 \pm 3 \mathrm{Ma}$ and $450 \pm 6$ Ma interpreted as the magmatic age (Roger et 
al., 2004; Cocherie et al., 2005). These Ordovician granitoids intruded a sedimentary series of grauwacke, pelite, quartzite, and rare marble, acidic or mafic magmatic layers (Demange et al., 1996; Alabouvette et al., 2003). Therefore, the Montagne Noire axial zone can no longer be considered as a Precambrian basement covered by Palaeozoic series as sometimes proposed (Demange et al., 1996). These rocks experienced a high temperature-low pressure metamorphism with tight isogrades (Bard and Rambeloson, 1973; Demange, 1982; Soula et al., 2001) that agrees well with the progressive crustal melting observed in centre of the dome. An earlier, presently undated, high-pressure metamorphism is documented by rare occurrence of kyanite in micaschist, and eclogite relics seldom preserved in amphibolite blocks (Demange, 1985; Alabouvette et al., 2003).

The core of the Espinouse dome consists of cordierite migmatites developed at the expense of augen orthogneiss and their host rocks. Metre to kilometre-sized HT gneiss septa are preserved (e.g. La Salvetat area). Moving into the dome core, migmatites progressively grade into the Laouzas cordierite anatectic granite (Gèze, 1949). Monazite from the Laouzas granite yields U-Th-Pb chemical age of $333 \pm 6$ Ma (Bé Mézème, 2005). The migmatite age obtained in several places by monazite U-Th-Pb chemical method ranges between 327 and 322 Ma (Bé Mézème, 2005).

The northwestern part of the axial zone is occupied by the Montalet pluton. This peraluminous granite was considered as an early body (Demange et al., 1996; Alabouvette et al., 2003). However, syn-magmatic monazites in this granite yield U-Th-Pb chemical ages at $327 \pm 7$ Ma and $333 \pm 4$ Ma (Bé Mézème, 2005; Charles et al., 2008). Furthermore, on the basis on our petrofabric observations and AMS measurements, we argue that the emplacement of the Montalet pluton is coeval with the migmatitic event. Thus, the relationships between the emplacement of the Montalet pluton and the doming must be reappraised.

Several small-sized, late to post-migmatitic delimited plutons intrude the axial zone (Figs. 1 and 2). They are either biotite-rich granite (e.g. Anglès granite) or muscovite-biotite \pm garnet leucogranites (e.g. Soulié, Vialais granites). Age of these plutons, determined by UTh-Pb chemical method on monazite, is comprised between 324-318 Ma (Bé Mézème, 2005; Charles et al., 2008). Lastly, several generations of garnet-tourmaline pegmatite and aplite dykes and sills intrude all the above-described rocks (Collot, 1980).

Therefore, from rim to core, the Montagne Noire axial zone appears as formed by concentric envelopes of micaschist, augen gneiss, migmatites, and anatectic granite. 


\subsection{Bulk architecture and kinematics}

In addition to the lithological zonation, the dome-shaped axial zone is also outlined by the attitude of the foliation in the micaschist and augen gneiss. Although the Espinouse dome is a rather symmetric structure, both Caroux antiform and Rosis synform are slightly overturned to the north (most likely due to a late Pyrenean stage; Fig. 2). In the metamorphic envelope of the Montagne Noire dome, the variably oriented foliation contains a pervasive consistently striking ENE-WSW (N70E) - mineral and stretching lineation marked by elongated augens in orthogneiss, biotite streaks, sillimanite nodule and fibres, pressure shadows around garnet, staurolite, and andalousite porphyroblasts. Kinematic analyses have demonstrated a contrasted pattern. In the western and eastern ends of the axial zone, NE-SW down-dip lineation is associated with top-to-the west and top-to-the east sense of shear, respectively (Beaud, 1985; Faure and Cottereau, 1988; Mattauer et al., 1996; Brunel and Lansigu, 1997; Soula et al., 2001). Conversely, along the dome flanks, the subhorizontal lineation is associated with a rather coaxial strain. This kinematic pattern has been invoked to argue that the Montagne Noire dome development resulted of the interference between an inflating diapir controlled by migmatites and granite emplacement and a regional strain field characterized by NE-SW stretching and NW-SE shortening (Faure and Cottereau, 1988; Mattauer et al., 1996; Soula et al., 2001).

\subsection{Macroscale structures in the dome core}

In the field, most of rock-types forming the Espinouse dome do not show any clear planar or linear fabrics. However, in migmatites and granitoids, several structures can be observed.

From south to north, the augen orthogneiss presents an increasing degree of migmatization. The initial foliation is progressively erased by crustal melting (Fig. 3a). Migmatite that occupies the central part of the Espinouse dome is variously foliated. In metatexites, a rather well developed foliation is characterized by the parallel arrangement of leucosomes and restites. Conversely, in diatexites, the paleosomes and leucosomes distribute more randomly.

In the Laouzas anatectic cordierite granite, a magmatic banding is sometimes defined by schlierens (Fig. 3b). Moreover, this granite contains numerous centimetre to several hundred metres enclaves of paragneiss host-rock that preserve their initial orientation. These 
enclaves have been used to draw the bulk geometry of the Espinouse dome (e.g. Gèze, 1949; Schuiling, 1960, Demange et al., 1996; Alabouvette et al., 2003).

In the Montalet biotite-garnet granite, an increase of deformation from south to north is illustrated by the fabric evolution, ranging from a poorly-defined foliation with a faint mineral lineation underlined by quartz and mica (Fig. 3c) to well-defined foliation, lineation and shear planes when approaching the MLF (Fig. 3d). Along the N30E lineation, kinematic indicators show a top-to-the-NE sense of shear (Fig. 4g). Post-anatectic granites, such as the Vialais or Soulié plutons exhibit a weakly developed planar preferred orientation of biotite and feldspar. Since the quartz grains remain globular, this fabric might have been formed in solid-state conditions.

Fig.3

\section{Petrofabric study}

The petrofabric study aims to characterize the relationships between blastesis and deformation of minerals. Mutual relationships of mineral, grain arrangements or intracrystalline microstructures of minerals allow us to estimate the rheological state of a rock when its fabric is acquired (e.g. Gapais and Barbarin, 1986; Hibbard, 1987; Paterson et al., 1989; Simpson and Wintsch, 1989). In the Montagne Noire axial zone, the different macroscopic fabrics are characterized by particular microstructures that can be related to distinct rheological conditions, namely magmatic, subsolidus and solidus stages. Furthermore, primary fabrics can be modified by subsequent deformation or annealing.

\subsection{Microstructure description}

In order to obtain textural information, about sixty geographically and lithologically representative thin-sections have been observed under the optical microscope. Four microstructure types can be distinguished for the rocks of the Montagne Noire axial zone (Fig. 5).

\subsubsection{Magmatic microstructure}

In the thin sections, coarse quartz grains design plurimillimetre-scale areas with weak undulatory extinction (Fig. 4a), and a few chess-board subgrains. Quartz grains are anhedral, non-deformed, non-aligned and do not exhibit a strong shape orientation; quartz grain joints are planar or weakly lobate. These features are typical of non-deformed granitoids (Paterson et al., 1989). 
-K-feldspars do not display ductile deformation features; they are unbroken and not surrounded by recrystallized aggregates. Plagioclase grains exhibit an oscillatory zoning and present euhedral or subhedral crystal habits (Fig. 4a). In the Montalet granite, myrmekites are conspicuously developed on feldspar faces perpendicularly to the foliation (Fig. 4b). In agreement with Hibbard (1987), we interpret myrmekite as an indicator of the deformation experienced by an incompletely crystallized rock.

-Biotite platelets are euhedral, mostly isolated in a groundmass of quartz and feldspar with magmatic microstructures. Biotite crystals have a sharp extinction and are neither kinked nor bent (Fig. 4a) without any evidence for intracrystalline deformation (Paterson et al., 1989).

\subsubsection{Weak solid-state fabric}

Minerals are more deformed than those present in the magmatically deformed rocks. -Quartz grains present undulatory extinction, and chess-board texture (Fig. 4c) formed by the coeval activity of both [100] (a quartz axis) and [001] (c quartz axis) dislocation slip. Quartz grains joints are lobate (Fig. 4d), or even slightly serrated. In some places, newly recrystallized and small sized quartz grains develop (Fig. 4d), arguing for the beginning of a dynamic recrystallization process.

-Feldspar grains present an undulatory extinction and subhedral crystals habits with several myrmekites (Fig. 4e).

-Biotite platelets are elongated but not deformed nor kinked, presenting very weak undulose extinction and are parallelly orientated defining a rough foliation. This microstructure formed under high temperature conditions during magma crystallization and is developed in the transitional rheological state between magmatic and solidus states.

\subsubsection{Moderate solid-state fabric}

In these rocks, the primary quartz grains are replaced by a mosaic of small recrystallized grains organized in ribbons. This mosaic texture of neograins with serrated boundaries is characteristic of dynamic recrystallization. However, aggregates and recrystallized grains do not exhibit a mylonitic fabric. Biotites are deformed and elongated (Fig. 4f). Feldspars often display intense undulatory extinction.

\subsubsection{Metamorphic and migmatitic fabric}


The microstructures described above occur in Laouzas and Montalet plutons. Metamorphic and migmatitic rocks show different microstructures. Biotites, inherited from foliated gneiss of the protoliths, are not elongated (Fig. 4h). Moreover, euhedral or subhedral quartz grains present a sharp extinction and straight boundaries (Fig. 4h). Feldspars have an undulatory extinction and several perthitic textures.

Fig.4

\subsection{Microstructure zonation}

At the scale of the entire Montagne Noire axial zone, the distribution of the above described microstructures shows a well-defined spatial organization (Fig. 5). Magmatic and weak-solid state deformation microstructures cover around $45 \%$ and $30 \%$ of the dome area, respectively. Magmatic microstructures are mainly located in the central part of the Laouzas pluton and in the post-migmatitic plutons (e.g. Anglès, Vialais). Weak solid-state deformation microstructures are observed in the contact between the Montalet and Laouzas plutons, in the post-migmatitic plutons (e.g. Soulié) and in the neighbouring migmatite. On the northern and northwestern borders of the Montalet pluton, microstructures of moderate solid-state deformation that represent around $10 \%$ of dome area are well developed in close vicinity to the Monts-de-Lacaune fault. In the south part of the dome, rocks presenting metamorphic and migmatitic fabric cover about $15 \%$ of the dome area. Thus, a decrease of deformation is observed from the edge to the centre of the migmatitic dome.

Fig.5

\section{Anisotropy Magnetic Susceptibility study}

In the field, the planar and linear structural elements are not clearly expressed in granite and migmatites. Particularly, in these rocks, even when a planar fabric can be directly observed in the field, a mineral lineation is never visible. Thus, in order to assess the fabric elements, an Anisotropy Magnetic Susceptibility (AMS) study has been carried out in the Montagne Noire axial zone.

\subsection{AMS Sampling}

For the AMS study, 830 cores from 135 sites have been sampled in several granitic facies, such as Laouzas, Montalet, Anglès, Soulié, Sécun-Combespinas granites, and migmatitic rocks (migmatite and migmatitic orthogneiss) in the dome located on the north of Eocene Mazamet thrust (Table 1 and Fig. 5). Sampling was carried out with a portable gasoline driller and the cores are oriented with magnetic and solar compasses, when it was 
possible. The average difference between magnetic and solar declinations is about $0.4^{\circ}$ and may be considered as negligible. Thus, cores oriented with magnetic compass alone did not undergo the declination correction. The cores were cut into standard specimens of $22 \mathrm{~mm}$ in length and $25 \mathrm{~mm}$ in diameter for the AMS measurements.

\subsection{Laboratory measurements and direction analyses}

The bulk magnetic susceptibility and AMS are measured with an AGICO KLY-3S Kappabridge apparatus at the Laboratoire de Magnétisme des Roches d’Orléans (CNRSUniversité d'Orléans). Magnetic hysteresis curves are obtained by a magnetic inductometer at the Laboratoire Paléomagnétique de Saint-Maur (IPG-Paris). The mean orientation of the three principal ellipsoidal axes of AMS $\left(\mathrm{K}_{1}>\mathrm{K}_{2}>\mathrm{K}_{3}\right)$ for groups of samples are computed with ANISOFT software using Jelinek’s statistic (Jelinek, 1981).

\subsection{Magnetic mineralogy}

Figure 6a shows the distribution of the bulk magnetic susceptibilities from different rock-types. More than $80 \%$ of sites reveal a weak magnetic susceptibility of $<200 \times 10^{-6}$ SI, being in the typical range of $\mathrm{Al}$-rich crustal granites and indicating that paramagnetic minerals are the principal carriers of the magnetic susceptibility (Bouchez, 2000). Two out of 135 sites show a bulk magnetic susceptibility higher than 800×10 $10^{-6}$ SI (Sites 69 and 71, Table 1). This unusual magnetic behaviour with respect to the majority of sites may be due to enrichment of magnetic minerals by posterior fluid circulation. Because of their weak representativity ( $<2 \%$ of total sites), these two sites are excluded for the further discussion. Figure $6 \mathrm{~b}$ presents representative hysteresis loops obtained from main rock facies of the Montagne Noire axial zone, showing a perfect linear relationship between the applied magnetic field (up to 1 Tesla) and induced magnetic moment (relatively low values of $<40 \times 10^{-3} \mathrm{Am}^{2} / \mathrm{kg}$ ). This observation confirms the measurement of the bulk magnetic susceptibility, demonstrating the predominance of paramagnetic minerals in this AMS collection (Fig. 6b). This conclusion is in agreement with both macro- and microscopic sample observations showing the abundance of biotite in all lithologies.

As mentioned above, cordierite can be commonly observed in the Laouzas granite and some migmatitic samples. This mineral carries an inverted magnetic fabric, i.e. the $\mathrm{K}_{1}$ and $K_{3}$ axes of the AMS ellipsoid are exchanged with respect to the external grain shape (Rochette et al., 1992) that can make confusion for the interpretation of the magnetic fabrics. In fact, we tried to avoid the sampling of granite with visible cordierite in the field. In thin- 
section of these cores, a few cordierite grains have been observed. They are far less abundant than biotite. Moreover, the cordierite magnetic susceptibility is ten times lower than that of biotite (Rochette et al., 1992). Thus, even if cordierite is present in our collection, it cannot significantly contribute to the AMS fabric. Consequently, biotite can be confidently considered as the main carrier of the magnetic susceptibility of this study. Therefore, the measured AMS is representative of the rock planar and linear mineral fabric. The $\mathrm{K}_{1}$ and $\mathrm{K}_{3}$ axes can be correlated to the lineation direction and foliation pole, respectively.

Fig.6

\subsection{Magnetic fabrics}

830 cores drilled from 135 sites of granite and migmatite of the Montagne Noire axial zone have been measured in the laboratory in order to obtain their planar and linear magnetic fabrics. The statistical results of these measurements are listed in Table 1.

Table 1

Less than $5 \%$ of sampled sites, which are essentially observed in migmatite and migmatitic orthogneiss show an anisotropy degree $\left(\mathrm{P}_{\mathrm{j}}\right)$ higher than $20 \%$, (Table 1 and Figure 7a). The generally weak $P_{j}$ value for the majority of samples indicates that the studied rocks have probably not suffered important deformations since the AMS acquisition. The shape parameter of AMS (T) shows a dominance of the planar anisotropy (i.e. magnetic foliation) with $\mathrm{T}$ value higher than 0 (Fig. 7). This implies that the AMS foliation is statistically better defined than the lineation. However, the statistics show only 7 sites out of 135 that present a dispersed lineation distribution with a confidence level $\left(\alpha_{95 \min }\right)$ higher than $20^{\circ}$ (Table 1$)$. No statistically reliable relationship can be established between anisotropy degree $\left(\mathrm{P}_{\mathrm{j}}\right)$ and shape parameter $(\mathrm{T})$, or with the bulk magnetic susceptibility parameter, Km, as well (Figs. 7b and $7 \mathrm{c})$.

Fig.7

Figure 8 presents the AMS principal axes $\left(\mathrm{K}_{1}, \mathrm{~K}_{2}\right.$, and $\left.\mathrm{K}_{3}\right)$ in equal-area projection for each site with respect to the different rock-types. The magnetic fabrics from the Montalet granitic pluton, in the northern part of the axial zone, are characterized by two distinct orientations (Fig. 8a). On the northern margin of the pluton, which is also the border of the axial zone, the magnetic lineations are mainly NE-SW oriented with variable foliation attitudes (e.g. Sites 78, 100, 123 in Fig. 8a). Away from the axial zone border and entering into the dome, the lineation shows an E-W trend (e.g. Sites 77, 83, 98 in Fig. 8a). This phenomenon is particularly remarkable in the Anglès and Vialais post-migmatitic plutons, as shown in Figure 8b. Near the pluton border, the NE-SW orientated lineation is dominant, and for the sites located inside the dome, a nearly E-W striking, highly dipping, lineation is dominant. The Laouzas granite covers the central part of the dome. The AMS behaviour is quite variable (Fig. 8c). It seems that this central part can be divided into two subzones. The 
northern one is characterized by a rather flat foliation and variably oriented lineation (Fig. 8c). In the southern subzone, the AMS of is characterized by both highly inclined, even vertical, foliation and lineation (Fig. 8c). The migmatites sampled along the axial zone of the dome show an E-W striking vertical or subvertical foliation, which is parallel to the dome long axis (Fig. 8d). The associated lineation is essentially E-W trending and weakly inclined, but a few vertical directions are also present (e.g. Sites 104, 124127 in Fig. 8d). Migmatitic orthogneiss distributed along the dome axis shows a rather consistent E-W magnetic lineation direction contained within a vertical foliation (Fig. 8e). In brief, it seems that the AMS distribution is not directly dependent of the rock-type, since similar trends can be observed in different lithologies. Conversely, whatever the facies, a distinct AMS distribution can be delineated depending on the site location within the dome-shaped structure.

Figure 9 assembles all the AMS site-mean directions measured in the different facies described above. From a statistical point of view, most measurements show a NE-SW striking, highly dipping foliation. In the northern part of the axial zone, occupied by the Montalet pluton in the northern flank of the Espinouse dome (Fig. 2), the NE-SW trending foliation gently dips to the north (Fig. 9a). A scattered foliation attitude, with a relatively weak inclination, characterizes the Laouzas granite and migmatites in the central part of the Espinouse dome (Figs. 2, 9a and 9c). Southwardly, the E-W trending foliation measured in the same anatectic granite, migmatites or migmatitic orthogneiss become highly dipping to the south, even subvertical, in the southern flank of the Espinouse dome (Figs. 9a and 9c). Moving farther to the south, the field structural observations show a southward dipping foliation, particularly well developed in the migmatitic orthogneiss. It is worth to note that the orientation of the magnetic foliation varies with the shape of the dome, in agreement with the macroscopic foliation that turns around the dome termination (Fig. 9a). Furthermore, the magnetic fabrics are consistent with the field observations made in the Laouzas pluton. There, the AMS foliation is parallel to the biotite-preferred orientation in schlierens or xenoliths arrangement (Fig. 9a). The average E-W orientation of the magnetic foliation is in agreement with the direction of the dome long axis (Fig. 9a).

The magnetic lineation bears a special interest for this study as it can be rarely observed in the field, especially for diatexites, anatectic granitoids and late granitoids. In map view, magnetic lineation shows contrasted trends from north to south throughout the Montagne Noire axial zone (Figs. 9b and 9c). In the northern part of the dome, the magnetic lineation is striking NE-SW (N40E) with a low dip to the north (Figs. 9b and 9c). In the central part, the lineation orientation becomes more scattered, although an ENE-WSW (N70E) trend, parallel to the dome long axis can still be recognized, some steeply plunging, 
even vertical, lineations are also present there (Figs. 9b and 9c). In the southern part of the dome, a more coherent E-W (N70E) pattern, parallel to the dome long axis, with flat inclination can also be defined (Figs. 9b and 9c). In order to qualitatively compare AMS results with available field observations, density contour diagrams have been calculated for individual AMS axes without the orthogonal constraint on three main axes (Fig. 9c; Borradaile and Gauthier, 2003; Jelinek, 1981).

Fig.9

\section{Discussion}

\subsection{Summary of petrofabric and AMS observations}

Microscopic petrofabric observations of representative samples of the Montagne Noire axial zone show that magmatic state and weak solidus deformation are the main characters for the AMS collection of this study. Magnetic mineralogical measurements identify the paramagnetic minerals, mainly biotite, as the principal carriers of the magnetic susceptibility. Detail AMS directional analyses of 135 sites show a lithology-independent and geographically correlated distribution for both magnetic lineation and foliation. Taking into account structural field observations in the Caroux orthogneiss dome, Figure 10 shows the double-dome architecture defined by both AMS and structural observations. This representation shows a consistent E-W oriented dome-parallel-axis foliation with a variable dip (Figs. 9a and 10a). The foliation dips to the north in the northern part, becomes nearly flat in the central part, and highly inclined to the south, or even vertical in the southern part. On the eastern and western dome terminations, the magnetic foliation follows the domeshape defined by the macroscopic foliation in gneiss (Figs. 9a and 10a). The pattern of the lineation distribution is less regular than the foliation. Nevertheless, the following tendencies can be derived (Figs. 9b and 10b): i) in the dome northern part, the lineation trends mainly NE-SW (N30E); ii) in the dome central part, two groups in the lineation trend can be identified, a highly inclined, or vertical one, and a parallel to the dome long axis (N70E) one; and iii) in the southern part, the AMS lineation is also parallel to the dome long axis (N70E) but contained in a vertical foliation.

Fig.10

\subsection{Chronology for the Montagne Noire evolution}

The above presented petrofabric, structural and AMS analyses provide new constraints on the Montagne Noire dome geometry. These indispensable informations must be combined with the available geochronological data to propose a reliable scenario for the 
emplacement of the granite-migmatite dome. Four main geological events are responsible for the evolution of the Montagne Noire and are summarized in the following with their relative Fig.11 ning (Fig. 11).

\subsubsection{Large-scale recumbent folding}

It is well acknowledged that in the southern French Massif Central, the last stage of the Variscan compression propagated from north to the south during the Carboniferous (Matte, 1991; Alabouvette et al., 2003; Faure et al., 2005). In Montagne Noire, thrusts and recumbent folds well developed in the southern zone (Figs. 1 and 2) are coeval with the sedimentation of syntectonic turbidites whose deposition age ranges from Late Visean to Early Namurian (330-325 Ma) in a foreland basin (Engel et al., 1980; Feist and Galtier, 1985).

\subsubsection{Migmatization}

The age of the migmatization is one of the critical arguments when dealing with the emplacement of the Montagne Noire dome. Curiously, until recently, no radiometric age was available for the axial zone migmatites and granitoids. The monazite U-Th-Pb chemical dating method developed by Cocherie and Albarède, (2001) has been applied to date the migmatization and plutonism in the Montagne Noire axial zone. Monazites from migmatites and anatectic granite yielded ages of $327 \pm$ 7, $333 \pm$ 6, $333 \pm 4$ Ma (Bé Mézème, 2005; Charles et al., 2008; Fig. 11). Thus, the 330-325 Ma time interval can be considered as that of the crustal melting event in the Montagne Noire axial zone. It is worth to note that this age is coeval with the development of the recumbent folds and thrusts in the dome northern and southern domains.

\subsubsection{Late to post-migmatitic plutonism}

Kilometre-scaled plutons with well-defined borders intrude the axial zone migmatites (Fig. 1). The magmatic foliation of these plutons develops lately with respect to the migmatitic foliation. In map view, the margin of the Vialais pluton is almost at right angle from the migmatitic foliation of the country rocks (Bogdanoff et al., 1984; Matte et al., 1998). Thus, from the structural point of view, the Vialais, Soulié, Anglès, and SécunCombespinas plutons and the numerous dykes that cross cut the axial zone migmatites can be considered as emplaced lately, after the development of the migmatitic foliation. Monazite from the Anglès, Vialais and Soulié plutons yields chemical U-Th-Pb ages of $325 \pm 7,320 \pm$ 
3, and 318 × 4 Ma, respectively (Bé Mézème, 2005; Charles et al., 2008; Fig. 11). The age of the Anglès pluton is statistically not significantly different from that of the migmatite, however, the ages of the Vialais and Soulié plutons are slightly younger than the migmatites. Therefore, this plutonism can be considered as a late to post-migmatization event in the axial zone.

6.2.4. Late-Carboniferous to Permian extension on the northern border of the dome

The Montagne Noire dome is bounded to the north by the ductile Monts-de-Lacaune Fault (MLF) and the brittle Graissessac fault (Figs. 1 and 2). Biotite and muscovite from mylonites, at the eastern extremity of the MLF, yielded ${ }^{40} \mathrm{Ar} /{ }^{39} \mathrm{Ar}$ ages of 308 and $297 \mathrm{Ma}$ (Maluski et al., 1991). These ages indicate that in the Late Carboniferous, the northeastern part of the dome was still around $350 \pm 50^{\circ} \mathrm{C}$ which is the closure temperature for $\mathrm{K}$ - $\mathrm{Ar}$ chronometer for biotite (Villa, 1998), but it does not necessary imply the activity of the MLF at this time. Indeed, infilling of the Stephanian Graissessac half-graben, and the subsequent Early Permian extensional basin is linked to the activity of the brittle Graissessac fault (Fig. 11).

\subsection{Emplacement mechanisms of the Montagne Noire dome}

Numerous structural and petrological observations have been carried out since several decades in the Montagne Noire axial zone to account for the doming mechanism (e.g. Gèze, 1949 ; Schuiling, 1960; Nicolas et al., 1977; Beaud, 1985; Faure and Cottereau, 1988; Echtler and Malavieille, 1990; Maluski et al., 1991; Van Den Driessche and Brun, 1992; Brun and Van Den Driessche, 1994; Mattauer et al., 1996; Brunel and Lansigu, 1997; Matte et al., 1998; Demange et al. 1999; Soula et al., 2001 and enclosed references). They can be grouped into three principal model types; however, due to incomplete arguments on the structure of the migmatites and Laouzas anatectic granite, none of them gives a satisfactory explanation of the dome formation. Before presenting a more comprehensive model that considers our new petro-textural and AMS data, a brief discussion of these models is provided below.

Fig.12

\subsubsection{Diapirism}

On the basis of the abundance of melted material in the dome core, and contrasted kinematics with a coaxial regime in the core of the dome and shearing top-to-E and top-to-W 
in the eastern and western dome extremities, respectively, a diapiric model has been invoked to account for the emplacement of the dome axial zone (Schuiling, 1960; Faure and Cottereau, 1988; Fig. 12a). The density difference between solid country rocks and melted rocks may create the gravitational instability responsible for the magma ascent (Soula et al., 2001). From our AMS study, the rheological features of the magmatic rocks, the flat magnetic foliation and the highly dipping magnetic lineation in the Laouzas granite and migmatite seem to support this hypothesis. However, the lack of radial distributed magnetic lineation and rim synclines suggests that diapirism alone cannot be the unique mechanism for the dome emplacement.

\subsubsection{Post-thickening collapse}

Several authors argued that a Late Carboniferous post-thickening collapse explains the emplacement of the Montagne Noire axial zone dome (Fig. 12b; Echtler and Malavieille, 1990; Van Den Driessche and Brun, 1992; Brun and Van Den Driessche, 1994; Brunel and Lansigu, 1997). This model mainly considers the mylonitic zone with top-to-the-NE kinematics located on the northeastern flank of the dome along the MLF (Brun and Van Den Driessche, 1994) and the Late Carboniferous Graissessac coal basin. The NNE-SSW trending magnetic lineation observed in the northern part of the dome during our study seems to be consistent with this model. However, the age of the mylonitic belt is disputable (see section 6.2). Furthermore, even if a ductile deformation developed at ca. $300 \mathrm{Ma}$, such an event is much younger than migmatization and plutonism dated around 330 Ma (Fig. 11; Bé Mézème, 2005; Charles et al., 2008). The 300 Ma deformation is related to the Late CarboniferousEarly Permian extensional tectonics that are already well identified as a general feature of the post-orogenic evolution of the French Massif Central (e.g. Faure, 1995). But the 30 Ma time gap between doming and coal basin formation precludes a direct relationship between the two events. At the time of the coal basin formation, the axial zone dome was already emplaced.

\subsubsection{Post-nappe anticline}

From structural and geochronological evidence, Matte et al. (1998) proposed that the axial zone dome is a post-nappe anticline that accommodated the ongoing N-S shortening already responsible for the recumbent folding (Fig. 12c). Our study shows that the magnetic lineation trends globally parallel to the dome long axis, especially on the southern flank of the dome, may support this hypothesis. Moreover, the radiometric ages from migmatitic and 
plutonic rocks indicate that melting developed coevally with the compressional tectonic event responsible for recumbent folding. However, some observations obtained by this new study cannot be explained by a post-nappe folding due to a N-S shortening: i) the NNE-SSW (N30E) magnetic lineation along the northern flank of the dome and close to the MLF; ii) the highly dipping magnetic lineation in the central part of the dome (even if a late refolding of nappes transport lineation could be involved); and iii) the magmatic texture observed in the Laouzas pluton in the core of the dome.

\subsubsection{A syn-compressional melting and diapiric rise}

Integrating all the available data, including the results from this study and previous ones, allow us to propose the following new scenario for the emplacement of the Montagne Noire dome (Fig. 13).

The Visean tectonics in the southern French Massif Central led to crustal thickening, as shown by recumbent folds and thrusts developed in the southern and northern zone. Crustal melting, likely triggered by the abundance of fluids in the sedimentary sequence, can be seen as a consequence of this crustal thickening. The geochronological results (Fig. 11) show that migmatization and formation of the Laouzas and Montalet plutons is coeval with the development of recumbent folds and formation of the foreland sedimentary basin. It is worth to note that crustal melting around $330 \mathrm{Ma}$ is widespread in the French Massif Central (e.g. Faure et al., 2005 and enclosed references). In the Montagne Noire axial zone, the flat magnetic foliation in the migmatites is in agreement with this structural pattern. The ca. 325 Ma Montalet pluton appears also as a synkinematic pluton coeval with compressional tectonics. However, the NE-SW magmatic lineation and the top-to-the-NE kinematics are associated to the development of the dextral-normal ductile MLF on the northern side of the pluton. Therefore, the MLF can be interpreted as a structure developed to accommodate the emplacement of the recumbent folds during the incipient formation of the dome.

It might be argued that the presently highly inclined magnetic lineation in the central part of the dome is due to a late refolding of an initially N-S trending lineation. However, the textural observation shows a lack of any post-solidus reworking as expected for folded foliation and lineation. Conversely, the magmatic texture observed in the Laouzas granite suggests that the planar and linear structure was acquired during a late stage of magma crystallization, still under sub-solidus state, likely in their present geometry. The subvertical magmatic lineation implies the contribution of vertical movement of magma during the doming. Such a magma vertical ascent is likely enhanced, if not completely accommodated, 
by density and viscosity contrasts between molten rocks and their host-rocks, i.e. by diapirism (Fig. 13a).

The compressional phase seems to have lasted, at least, until the emplacement of the youngest late to post-migmatitic granitic Anglès, Vialais, Soulié and Sécun-Combespinas plutons, around 325-310 Ma (Fig. 13b), because these younger plutons show a subvertical magnetic foliation and a subhorizontal magnetic lineation consistent with other graniticmigmatitic rocks from the southern part of the dome.

The late stage of the tectonic evolution in the Montagne Noire, around $300 \mathrm{Ma}$, corresponds to the formation and the infilling of the Graissessac coal basin bounded to the south by the brittle Graissessac fault (Fig. 13c). This Late Carboniferous-Early Permian NESW extensional regime is general in the French Massif Central (e.g. Faure, 1995).

Fig.13

\section{Conclusions}

In order to better understand the emplacement mechanism of the axial zone dome and its place in the tectonic evolution of the Montagne Noire, a detail petrofabric and AMS study has been carried out covering the main rock-types and the largest surface of the dome. The microscopic observations indicate that the deformation experienced by the migmatites and granitic plutons that form the main part of the dome occurred under subsolidus or weak solidstate rheology. The paramagnetic minerals, such as biotite, are identified as the main carrier of the magnetic susceptibility. The magnetic fabrics measured from 830 cores of 135 sites yield planar and linear distributions independent of the lithology but correlated with the dome architecture. From north to south, the magnetic lineation presents contrasted trend, namely a NE (N40E) weakly dipping orientation in the north, nearly vertical dip in the centre and a ENE-WSW (N70E) strike, parallel to the dome long axis, in the south. The magnetic foliation is oriented NE-SW and gently dipping to the north in the north, flat lying in the centre, and NE-SW trending highly dipping to the south in the south. Coupling these new results from this study with previous observations, the newly proposed hypothesis accounts for the mechanism of the emplacement of the Montagne Noire dome (Fig. 13).

Between 340-325 Ma, during the Variscan orogeny, the Ordovician granitoids and their country rocks underwent the synmetamorphic compressional tectonics responsible for thrust sheets and recumbent folds similar to those recognized in the Palaeozoic series of the Montagne Noire southern and northern flanks. Crustal melting represented by migmatization and plutonism developed coevally with the compressional tectonics. Gravity and viscosity driven diapiric processes enhanced the development of the axial zone dome (Fig. 13). Around $325 \mathrm{Ma}$, a dextral-normal faulting occurred along the MLF, in the northeastern part 
of the dome. This late event might modify or overprint the previous magnetic fabric orientations of the Montalet pluton. This fault also facilitated the final exhumation of the dome. The extensional event took place after the late to post-migmatitic plutonism. Around $300 \mathrm{Ma}$, coal-bearing half-graben formation and infill (e.g. Graissessac basin) occurred along the brittle Graissessac fault with the generalized post-thickening collapse of the Variscan Belt.

\section{Acknowledgments}

This work is a contribution to the "Programme de la Carte Géologique de la France au 1/50 000” Castres sheet, and its explanatory notes. The BRGM (French Geological Survey) is thanked for the financial support. AMS measurements were partly carried out at the Institut de Physique du Globe de Paris (Saint-Maur). We thank Dr. Jackson, Dr. Borradaile and anonymous reviewer for their constructive suggestions to improve our manuscript.

\section{References}

Alabouvette, B., Demange, M., Guérangé-Lozes, J., Ambert, P., 2003. Notice explicative de la carte géologique de Montpellier. Carte géologique (38) par Berger, G., Alabouvette, B., Guérangé-Lozes, J., Demange, M., Ambert, P., 2001. Bureau de Recherches Géologiques et Minières, scale 1:250,000.

Arthaud, F., 1970. Etude tectonique et microtectonique comparée de deux domaines hercyniens : les nappes de la Montagne Noire (France) et l'anticlinorium de l'Iglesiente (Sardaigne). Ph.D. thesis, Université de Montpellier.

Asrat, A., Gleizes, G., Barbey, P., Ayalew, D., 2003. Magma emplacement and mafic-felsic magma hybridization: structural evidence from the Pan-African Negash pluton, Northern Ethiopia. Journal of Structural Geology 25, 1451-1469.

Bard, J.-P. and Rambeloson, R., 1973. Métamorphisme plurifacial et sens de variation du degré géothermique durant la tectogenèse polyphasée hercynienne dans la partie orientale de la zone axiale de la Montagne Noire (massif du Caroux, sud du Massif Central français). Bulletin de la Société Géologique de France 15, 579-586.

Bé Mézème, E., 2005. Contribution de la géochronologie U-Th-Pb sur monazite à la compréhension de la fusion crustale dans la chaîne Hercynienne française et implication géodynamique. Ph.D. thesis, Université d'Orléans.

Beaud, F., 1985. Etude structurale de la zone axiale de la Montagne Noire (sud du Massif Central français). Détermination des mécanismes de déformation, relation avec les nappes du versant sud. Ph.D. thesis, Université des Sciences et Techniques du Languedoc.

Benn, K., Ham, N.M., Pignotta, G.S., Bleeker, W., 1998. Emplacement and deformation of granites during transpression: magnetic fabrics of the Archean Sparrow pluton, Slave Province, Canada. Journal of Structural Geology 20, 1247-1259. 
Bogdanoff, S., Donnot, M., Ellenberger, F., 1984. Carte géologique de Bédarieux. Carte géologique de la France (988), Bureau de Recherches Géologiques et Minières, scale $1: 50,000$.

Borradaile, G.J., 1988. Magnetic susceptibility, petrofabrics and strain. Tectonophysics 156, $1-20$.

Borradaile, G.J., Henry, B., 1997. Tectonic applications of magnetic susceptibility and its anisotropy. Earth Science Reviews 42, 49-93.

Borradaile, G.J., Gauthier, D., 2003. Emplacement of an Archean gneiss dome, northern Ontario, Canada: Inflation inferred from magnetic fabrics. Tectonics 22(2), 1011, doi: 10.1029/2002TC001443.

Bouchez, J., 2000. Anisotropie de susceptibilité magnétique et fabrique des granites. Comptes Rendus de l’Académie des Sciences 330, 1-14.

Brown, M., 2005. Synergistic effects of melting and deformation: an example from the Variscan belt, western France. In: Deformation mechanisms, rheology and tectonics: from minerals to the lithosphere, Geological Society of London, Special Publication 243, 205-226.

Brun, J.-P., Van Den Driessche, J., 1994. Extensional gneiss dome and detachment fault systems: structure and kinematics. Bulletin de la Société Géologique de France 165, 519-530.

Brunel, M., Lansigu, C., 1997. Déformation et cinématique de mise en place du dôme de la zone axiale de la Montagne Noire: signification des nodules à quartz-sillimanite (Massif Central français). Comptes Rendus de l’Académie des Sciences 325, 517-523.

Carreras, J. and Capella, I., 1994. Tectonic levels in the Palaeozoic basement of the Pyrenees: a review and new interpretation. Journal of Structural Geology 16, 1509-1524.

Charles, N., Faure, M., Chen, Y., 2008. The emplacement of the Montagne Noire axial zone (French Massif Central): New insights from petro-textural, geochronological and AMS studies. $22^{\text {ème }}$ Réunion des Sciences de la Terre, Nancy, 155.

Cocherie, A., Albarède, F., 2001. An improved U-Th-Pb age calculation for electron microprobe dating of monazite. Geochimica et Cosmochimica Acta 65, 4509-4522.

Cocherie, A., 2003. Datation avec le SHRIMP II du métagranite oeillé du Somail-Montagne Noire. Compte Rendu technique ANA-ISO/NT, BRGM.

Cocherie, A., Baudin, T., Autran, A., Guenot, C., Mark Fanning, C., Laumonier, B., 2005. U$\mathrm{Pb}$ zircon (ID-TIMS and SHRIMP) evidence for the Early Ordovician intrusion of metagranites in the Late Proterozoic Canaveilles group of the Pyrénées and the Montagne Noire. Bulletin de la Société Géologique de France 176, 269-282.

Collot, B., 1980. Les filons aplito-pegmatitiques du massif du Caroux (Montagne Noire) : déformation et mécanismes de mise en place. Bulletin du BRGM $2^{\text {ème }}$ série 4, 257-267.

Davis, G.H., Coney, P.A., 1979. Geologic development of the Cordilleran metamorphic core complex. Geology 7, 120-124. 
Demange, M., 1982. Etude géologique du Massif de l’Agout, Montagne Noire, France. Ph.D. thesis, Université de Paris VI.

Demange, M., 1985. The eclogite-facies rocks of the Montagne Noire, France. Chemical Geology 50, 173-188.

Demange, M., Guérangé-Lozes, J., Guérangé, B., 1996. Carte géologique de Lacaune et sa notice. Carte géologique de la France (987), Bureau de Recherches Géologiques et Minières, scale 1:50,000.

Demange, M., 1999. Evolution tectonique de la Montagne Noire : un modèle en transpression. Comptes Rendus de l’Académie des Sciences 329, 823-829.

Echtler, H. and Malavieille, J., 1990. Extensional tectonics, basement uplift and StephanoPermian collapse basin in a late Variscan metamorphic core complex (Montagne Noire, southern Massif Central). Tectonophysics 177, 125-138.

Engel, W., Feist, R., Franke, W., 1980. Le Carbonifère anté-stéphanien de la Montagne Noire : rapports entre mise en place des nappes et sédimentation. Bulletin du BRGM 2, 341389.

Eskola, P., 1949. The problem of mantle gneiss domes. Geological Society of London, Quarterly Journal 104, 461-476.

Faure, M. and Cottereau, N., 1988. Données cinématiques sur la mise en place du dôme migmatitique Carbonifère moyen de la zone axiale de la Montagne Noire (Massif Central, France). Comptes Rendus de l’Académie des Sciences 307, 1787-1794.

Faure, M., 1995. Late orogenic Carboniferous extensions in the Variscan French Massif Central. Tectonophysics 14, 132-153.

Faure, M., Leloix, C., Roig, J.-Y., 1997. L'évolution polycyclique de la chaîne Hercynienne. Bulletin de la Société Géologique de France 168, 695-705.

Faure, M., Ledru, P., Lardeaux, J.-M., Matte, P., 2004. Paleozoic orogenies in the French Massif Central. A cross section from Béziers to Lyon. $32^{\text {nd }}$ International Geological Congress Florence (Italy), Field trip guide book, 40p.

Faure, M., Bé Mézème, E., Duguet, M., Cartier, C., Talbot, J.-Y., 2005. Paleozoic tectonic evolution of Medio-Europa from the example of the French Massif Central and Massif Armoricain. Journal of Virtual Explorer, Electronic edition, ISSN 1441-8142 19, paper 5.

Feist, R. and Galtier, J. (1985). Découverte de flores d'âge namurien probable dans le flysch à olistolithes de Cabrières (Hérault). Implications sur la durée de la sédimentation synorogénique dans la Montagne Noire (France Méridionale), Comptes Rendus de l’Académie des Sciences 300, 207-212.

Ferré, E.C., Teyssier, C., Jackson, M., Thill, J.W., Rainey, E.S.G., 2003. Magnetic susceptibility anisotropy: a new petrofabric tool in migmatites. Journal of Geophysical Research 108, 2086-2100.

Gapais, D. and Barbarin, B., 1986. Quartz fabric transition in a cooling syntectonic granite (Hermitage Massif, France). Tectonophysics 125, 357-370. 
Gèze, B., 1949. Etude géologique de la Montagne Noire et des Cévennes méridionales. Mémoire de la Société Géologique de France 62, 1-215.

Hamet, J. and Allègre, C., 1976. Hercynian orogeny in the Montagne Noire (France). Application of ${ }^{87} \mathrm{Rb}^{87} \mathrm{Sr}$ systematics. Geological Society of America Bulletin 87, 14291442.

Hibbard, M., 1987. Deformation of incompletely crystallized magma systems: granitic gneisses and their tectonic implications. Journal of Geology 95, 543-561.

Jelinek, V., 1981. Characterization of the magnetic fabric of rocks. Tectonophysics 79, 563567.

Ledru, P., Lardeaux, J.-M., Santallier, D., Autran, A., Quenardel, J.-M., Floc'h, J.-P., Lerouge, G., Maillet, N., Marchand, J., Ploquin, A., 1989. Où sont les nappes dans le Massif Central français ? Bulletin de la Société Géologique de France 5, 605-618.

Maluski, H., Costa, S., Echtler, H., 1991. Late Variscan tectonic evolution by thinning of earlier thickened crust. An ${ }^{40} \mathrm{Ar}-{ }^{39} \mathrm{Ar}$ study of the Montagne Noire, southern Massif Central, France. Lithos 26, 287-304.

Mattauer, M., Laurent, P., Matte, P., 1996. Plissement Hercynien synschisteux post-nappe et étirement subhorizontal dans le versant sud de la Montagne Noire (sud du Massif Central, France). Comptes Rendus de l’Académie des Sciences 322, 309-315.

Matte, P., 1991. Accretionary history and crustal evolution of the Variscan Belt in western Europe. Tectonophysics 196, 309-337.

Matte, P., Lancelot, J., Mattauer, M., 1998. La zone axiale Hercynienne de la Montagne Noire n'est pas un "metamorphic core complex" extensif mais un anticlinal post-nappe à cœur anatectique. Geodinamica Acta 11, 13-22.

Mezger, J. E., in press. Minor significance of orogen-parallel extension in the Variscan Axial Zone of the Pyrenees. Bulletin de la Société Géologique de France.

Nicolas, A., Bouchez, J.-L., Blaise, J., Poirier, J., 1977. Geological aspects of deformation in continental shear zones. Tectonophysics 42, 55-73.

Paterson, S.R., Vernon, R.H., Tobisch, O.T., 1989. A view of criteria for the identification of magmatic and tectonic foliations in granitoids. Journal of Structural Geology 11, 349-363.

Ramberg, H., 1967. Gravity, deformation and the earth's crust. Academic Press, London, 452p.

Ramberg, H., 1980. Diapirism and gravity-collapse in the Scandinavian Caledonides. Journal of the Geological Society of London 137, 262-270.

Rochette, P., Jackson, M., Aubourg, C., 1992. Rock magnetism and the interpretation of anisotropy of magnetic susceptibility. Reviews of Geophysics 30, 209-226.

Roger, F., Respaut, J.-P., Brunel, M., Matte, P., Paquette, J.-L., 2004. Première datation U-Pb des orthogneiss oeillés de la zone axiale de la Montagne Noire (sud du Massif Central) : 
nouveaux témoins du magmatisme ordovicien dans la chaîne Varisque. Comptes Rendus Géoscience 336, 19-28.

Schuiling, R., 1960. Le dôme gneissique de l'Agoût (Tarn et Hérault). Mémoire de la Société Géologique de France, 91.

Simpson, C. and Wintsch, R.P., 1989. Evidence for deformation-induced K-feldspar replacement by myrmekite. Journal of Metamorphic Geology 7, 261-275.

Soula, J.-C., Debat, P., Brusset, S., Bessière, G., Christophoul, F., Deramond, J., 2001. Thrust-related, diapiric and extensional doming in a frontal orogenic wedge: example of the Montagne Noire, southern French Hercynian belt. Journal of Structural Geology 23, 16771699.

Talbot, J.-Y., Martelet, G., Courrioux, G., Chen, Y., Faure, M., 2003. Emplacement in an extensional setting of the Mont-Lozère-Borne granitic complex (SE France) inferred from comprehensive AMS, structural and gravity studies. Journal of Structural Geology 26, 11-28.

Talbot, J.-Y., Faure, M., Chen, Y., Martelet G. 2005a. Pull apart emplacement of the Margeride granitic complex (French Massif Central). Implications for the late evolution of the Variscan orogen. Journal of Structural Geology 27, 1610-1629.

Talbot, J.-Y., Chen, Y., Faure, M., 2005b. Pluton-dykes relationships from AMS and microstuctural studies in a Variscan granite from French Massif Central. Journal of Geophysical Research 110, B12106, doi:10.1029/2005JB003699.

Van Den Driessche, J. and Brun, J.-P., 1992. Tectonic evolution of the Montagne Noire (French Massif Central): a model of extensional dome. Geodinamica Acta 5, 85-99.

Villa, I.M., 1998. Isotopic closure. Terra Nova 10, 42-47.

Vissers, R., 1992. Variscan extension in the Pyrenees. Tectonics 11, 1369-1384.

Wernicke, B. and Burchfield, B.C., 1982. Modes of extensional tectonics. Journal of Structural Geology 4, 105-115.

Whitney, D.L., Teyssier, C., Siddoway, C.S., 2004. Gneiss domes in orogeny. Geological Society of America, Special Paper 380, 393p.

Zwart, H. J., 1986. The Variscan orogeny of the Pyrenees. Tectonophysics 129, 9-27.

\section{Figure captions}

Figure 1: Structural map of the Montagne Noire (modified from Gèze, 1949 and Arthaud, 1974). 
Figure 2: Synthethic geological cross section in the Montagne Noire (after Faure et al., 2004).

Figure 3: Outcrop photographs showing characteristic structures. (a) Migmatitic orthogneiss (Saut de Vésole), (b) schlierens in the Laouzas granite (east of La Salvetat), (c) lineation (L) underlined by quartz in the Montalet granite (Pic de Montalet) and (d) foliation and shearing planes with lineation (L) in the Montalet granite (Col de Picotalen).

Figure 4: Microstructures defined in the Montagne Noire axial zone. (a) and (b) Magmatic and late-magmatic microstructures with myrmekites developed perpendicularly to the foliation (Laouzas and Montalet granites, respectively). (c)-(e) Microstructures of weak solid-state deformation. (c) Chess-board quartz grains (Montalet granite). (d) Quartz grains are partially recrystallized with a few neograins formation and lobate borders (Laouzas granite). (e) Myrmekite on a feldspar border (Laouzas granite). (f)-(g) Microstructures of moderate solid-state deformation. (f) Intensively recrystallized quartz grains with reduced grain size and biotite beds (Montalet granite). (g) Deformed feldspar showing a top-to-the N30 kinematic (Montalet granite). (h) Microstructures linked to metamorphism and migmatization (Migmatitic orthogneiss). Kfs: potassic feldspar, pl: plagioclase, qz: quartz, bi: biotite, myr: myrmekite, F: foliation.

Figure 5: Distribution map of the different types of microstructures in the Montagne Noire axial zone (limited to the north by the Monts-de-Lacaune fault). The area of the Laouzas granite (limited by dashed-dotted line) and migmatite is characterized by magmatic microstructures and corresponds to the dome core which is limited by dashed line. In the Montalet pluton, the deformation gradient progresses from weak solid-state to moderate solid-state microstructures towards the Monts-de Lacaune-fault. Black dots represent AMS sampling sites. Only the part of the dome located to the north of the Mazamet Eocene thrust is represented here.

Figure 6: Magnetic mineralogical experiments. (a) Histogram of bulk magnetic susceptibility distribution according to main lithologies of the axial zone. (b) Hysteresis cycles of main lithologies in the axial zone, showing linear relationship between the applied magnetic field and the induced magnetic moment.

Figure 7: AMS scalar parameters for each site and main lithologies in the axial zone. (a) T (shape parameter) vs. $\mathrm{P}_{\mathrm{j}}$ (corrected anisotropy degree), (b) $\mathrm{T}$ (shape parameter) vs. Km (mean bulk magnetic susceptibility in $10^{-6} \mathrm{SI}$ ) and (c) $\mathrm{P}_{\mathrm{j}}$ (corrected anisotropy degree) vs. Km (mean bulk magnetic susceptibility in $10^{-6} \mathrm{SI}$ ). The calculations of $\mathrm{T}$ and $\mathrm{P}_{\mathrm{j}}$ can be found in Jelinek (1981).

Figure 8: Equal-area projection of AMS results of each site for each lithology: (a) Montalet granite, (b) post-migmatitic granites, (c) Laouzas granite, (d) migmatitic orthogneiss and (e) 
migmatite in the Montagne Noire axial zone. Squares and circles stand for $\mathrm{K}_{1}$ (magnetic lineation) and $\mathrm{K}_{3}$ (pole of magnetic foliation), respectively. Small grey dots and larger black ones represent individual specimen and site-mean direction, respectively. Confidence ellipses at 95\% level are drawn around site-mean direction. Only the part of the dome located to the North of Mazamet Eocene thrust is represented here.

Figure 9: Magnetic fabric maps of granitic and migmatitic rocks in the Montagne Noire axial zone. (a) and (b) present magnetic foliation and lineation maps, respectively. The field observations are also presented. (c) Equal-area projections (lower hemisphere) show the density contours of individual AMS axes $(\mathrm{F}=$ foliation pole, $\mathrm{L}=$ lineation) for three geographic parts of the axial zone (northern, centre and southern). Only the part of the dome located to the north of Mazamet Eocene thrust is represented here.

Figure 10: Bloc diagram of the Montagne Noire axial zone with synthesis of linear and planar structural elements issued from AMS study. The attitude of magnetic foliation complies with preferred orientation of biotite, schlierens, enclaves and with migmatitic foliation. The AMS fabric confirms the elliptical shape of the axial zone inferred from migmatitic and gneissic envelope. The southward dipping foliation recognized in both flanks is in agreement with an asymmetric dome. Magnetic lineation exhibits a contrasted pattern with a dominant NE-SW trend, and also N-S one. In the Laouzas pluton, subvertical and subhorizontal AMS lineations illustrate different structural levels of a diapir.

Figure 11: Geochronological synthesis in the Montagne Noire axial zone with: chemical U$\mathrm{Th}-\mathrm{Pb}$ ages on monazite for the emplacement of rocks (Migmatite; Laouzas, Montalet, Anglès, Vialais and Soulié plutons), and radiometric Ar-Ar ages on biotite and muscovite for the deformation in the Caroux dome, the southern Caroux dome border and mylonite (northeastern Espinouse dome border: Monts de Lacaune fault).

Figure 12: The different proposed models for the emplacement of the Montagne Noire axial zone.

Figure 13: Model for the emplacement of the Montagne Noire axial zone. (a) 340-325 Ma: Diapirism and compressional setting with the fold and thrust nappes emplacement coeval with crustal melting: migmatization, Laouzas and Montalet plutons emplacement at depth and synsedimentary recumbent folds in the Visean foreland basin. The synkinematic emplacement of the Montalet pluton is associated to the Monts de Lacaune fault (MLF). The early stage of exhumation of the dome is accommodated with diapirism and compressional tectonics. (b) 325-310 Ma: Post-migmatitic intrusion of Anglès, Vialais, Soulié and SécunCombespinas plutons, and dome amplification. (c) 300 Ma: Post-thickening collapse with Graissessac coal half-graben infill and final exhumation of the dome due to normal-dextral faulting along Graissessac fault. 
Table 1: The results of AMS measurements of granites and migmatites from the Montagne Noire axial zone. n: number of specimens. Dec, Inc, $\alpha_{95 \min }, \alpha_{95 \max }$ are declination, inclination, Jelinek's statistic confidence at 95\% level (Jelinek, 1981) in degrees, respectively. $\mathrm{P}_{\mathrm{j}}$ : Corrected anisotropy degree, T: Anisotropy shape parameter (Jelinek, 1981), and Km: Mean bulk magnetic susceptibility. Letters correspond to main lithologies in the Montagne Noire axial zone with M: migmatite, G: granite, OM: migmatitic orthogneiss, GV: Vialais granite, GL: Laouzas granite, GM: Montalet granite, LeucoG: leucogranite, GSC: Sécun-Combespinas granite, GS: Soulié granite, GA: Anglès granite, CB: basic body. 


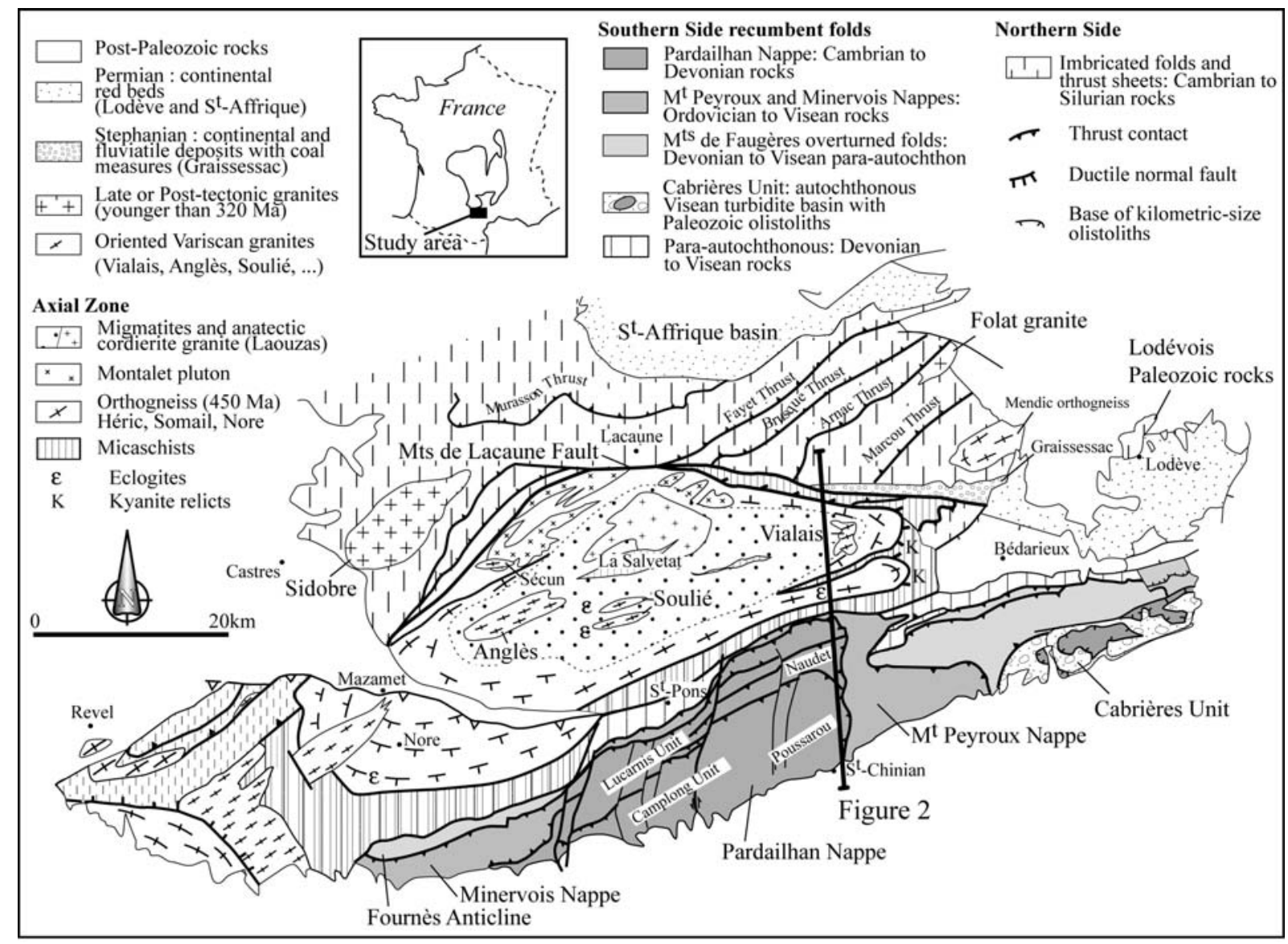

Figure 1

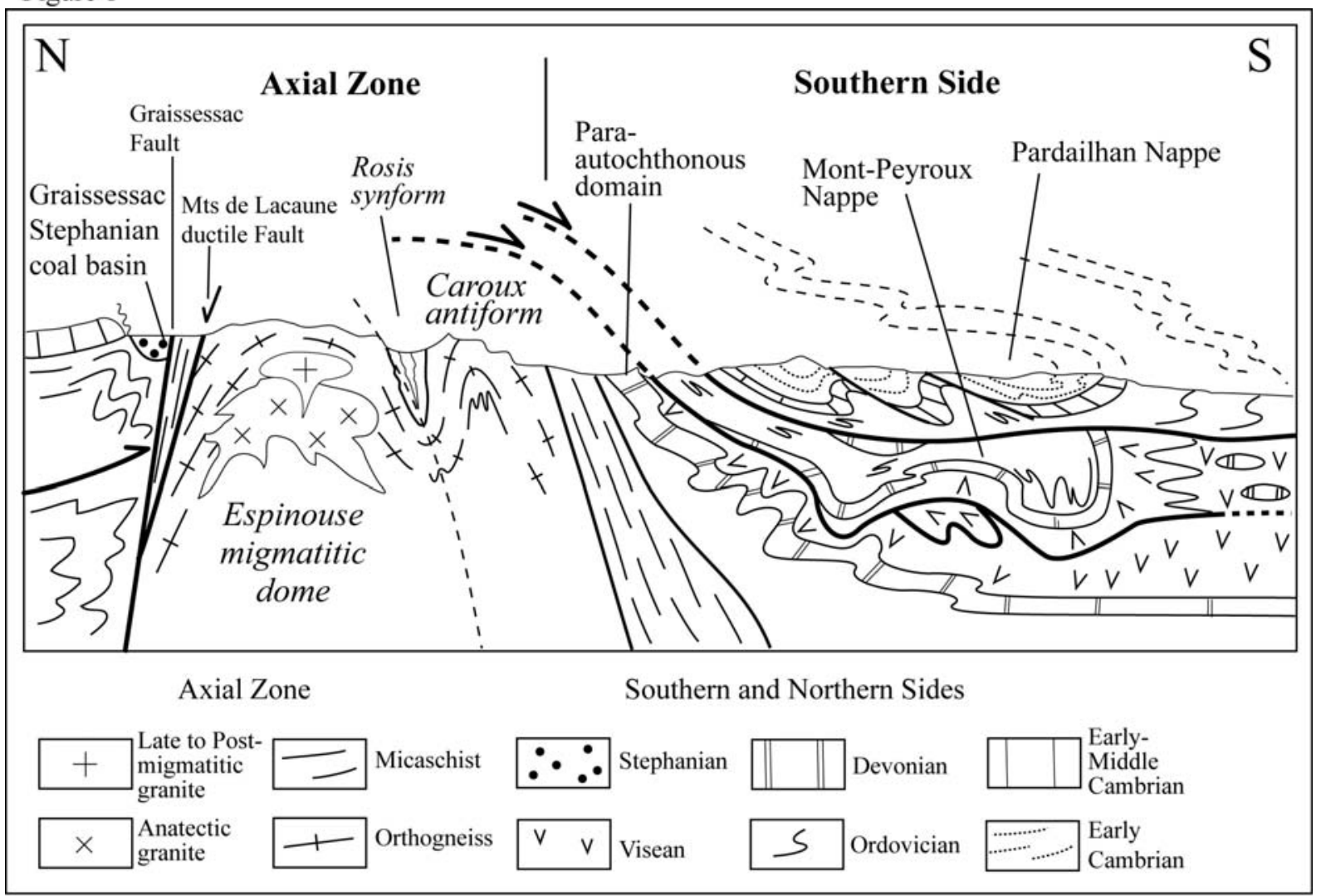

Figure 2 

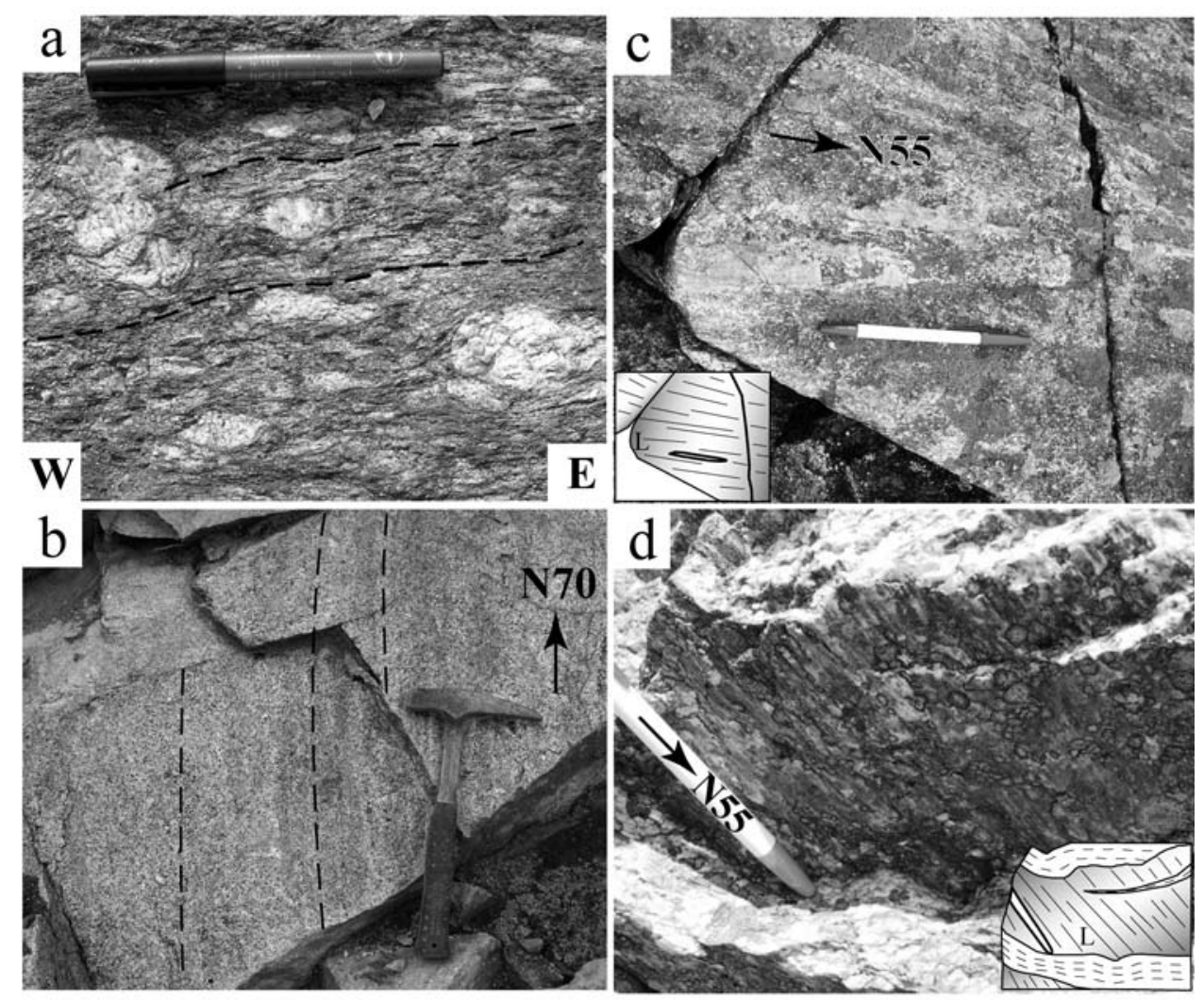

Figure 3 

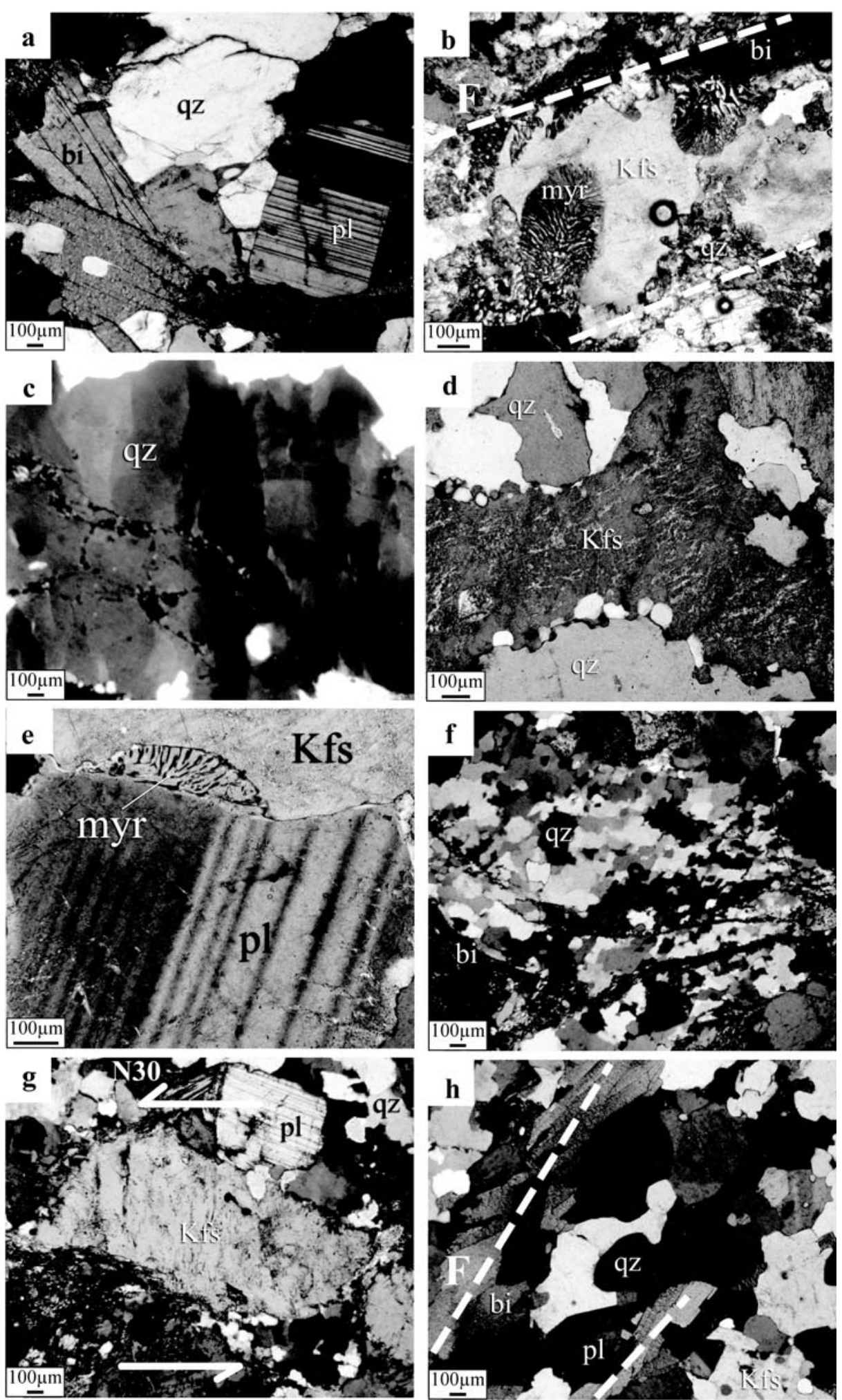

Figure 4 


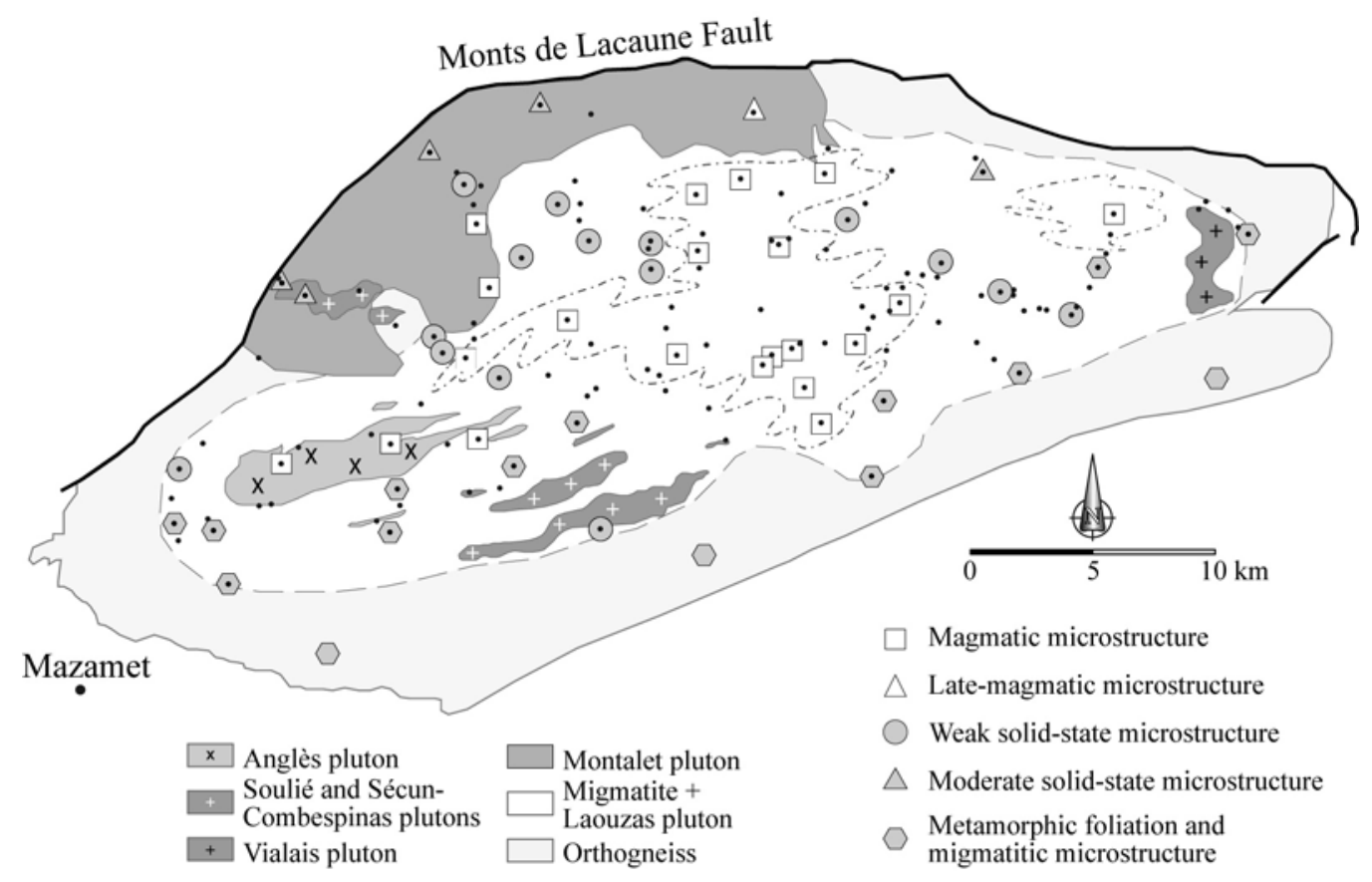

Figure 5

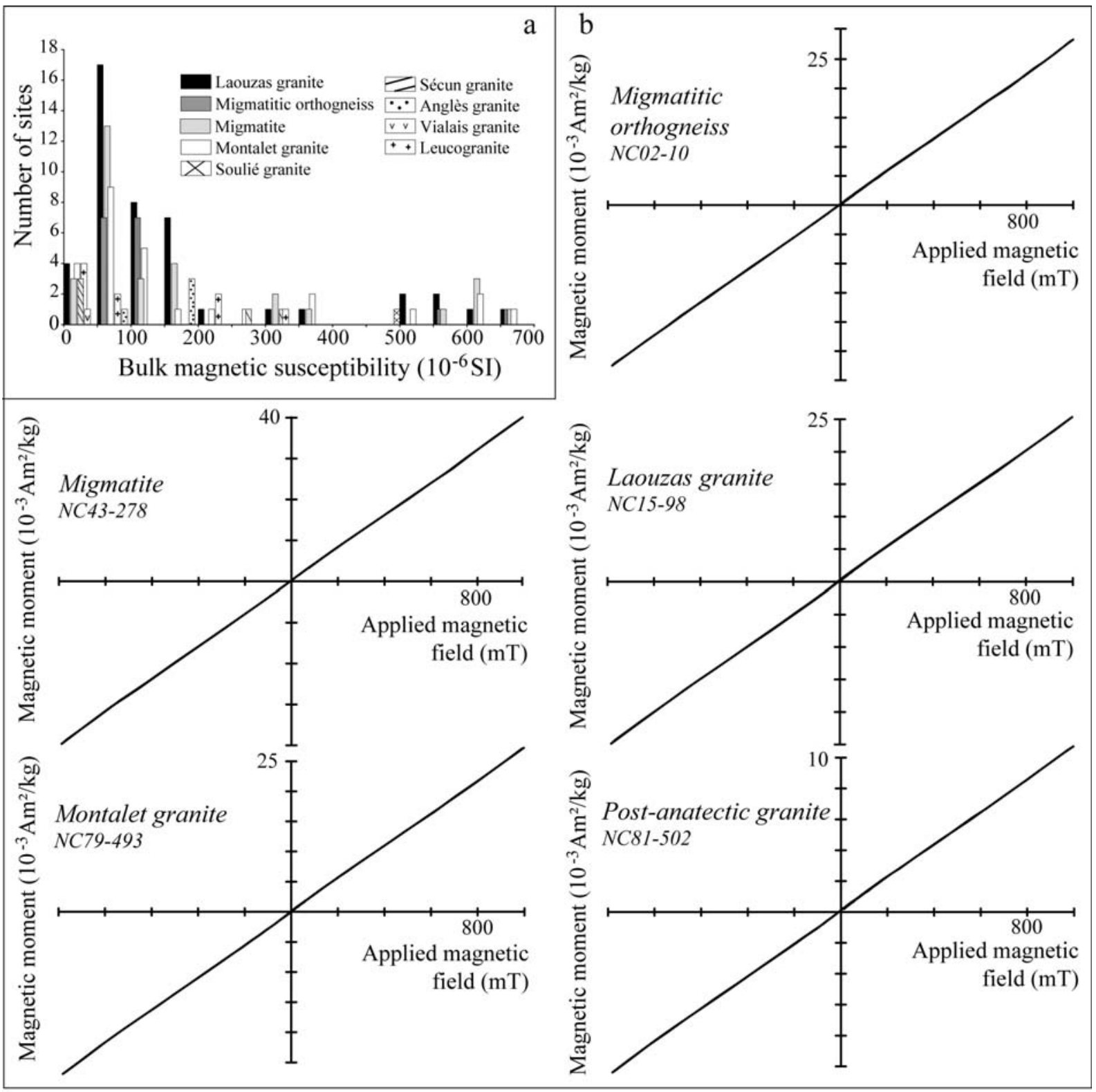

Figure 6 

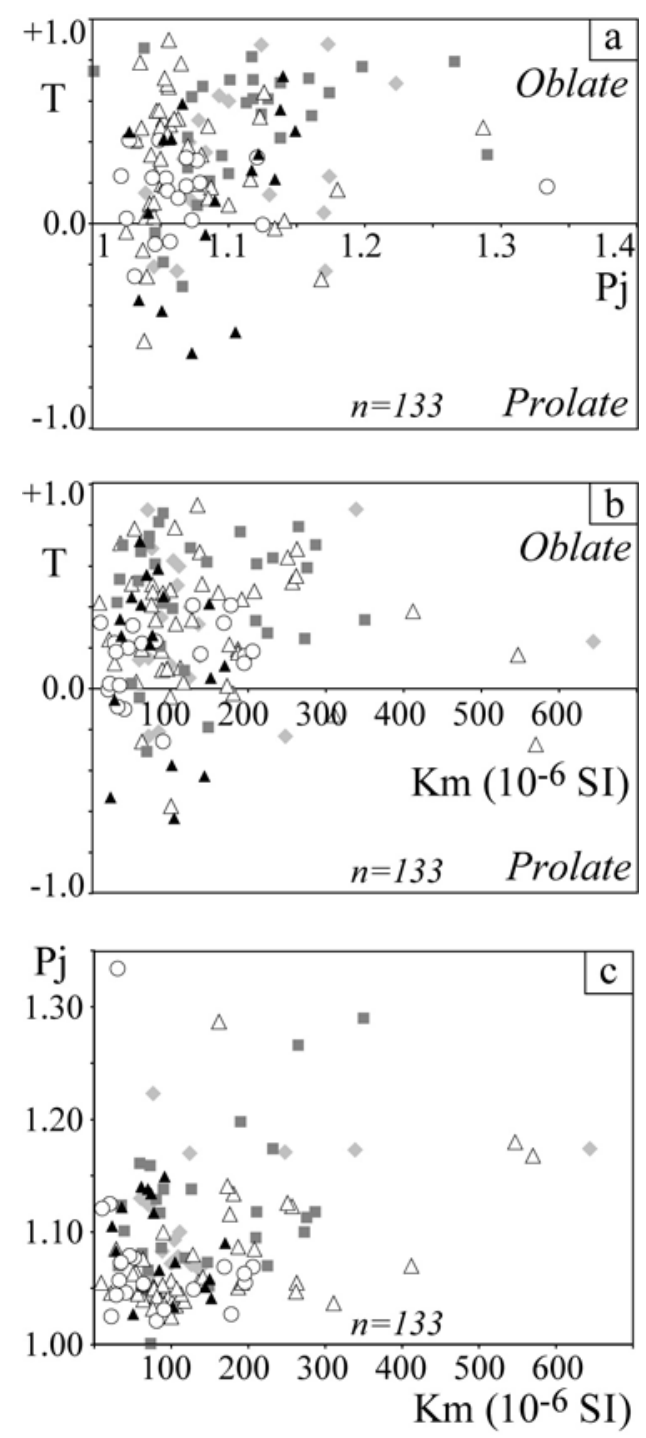

- Migmatitic orthogneiss - Migmatite

$\triangle$ Laouzas granite $\Delta$ Montalet granite - Post-anatectic granite

Figure 7 


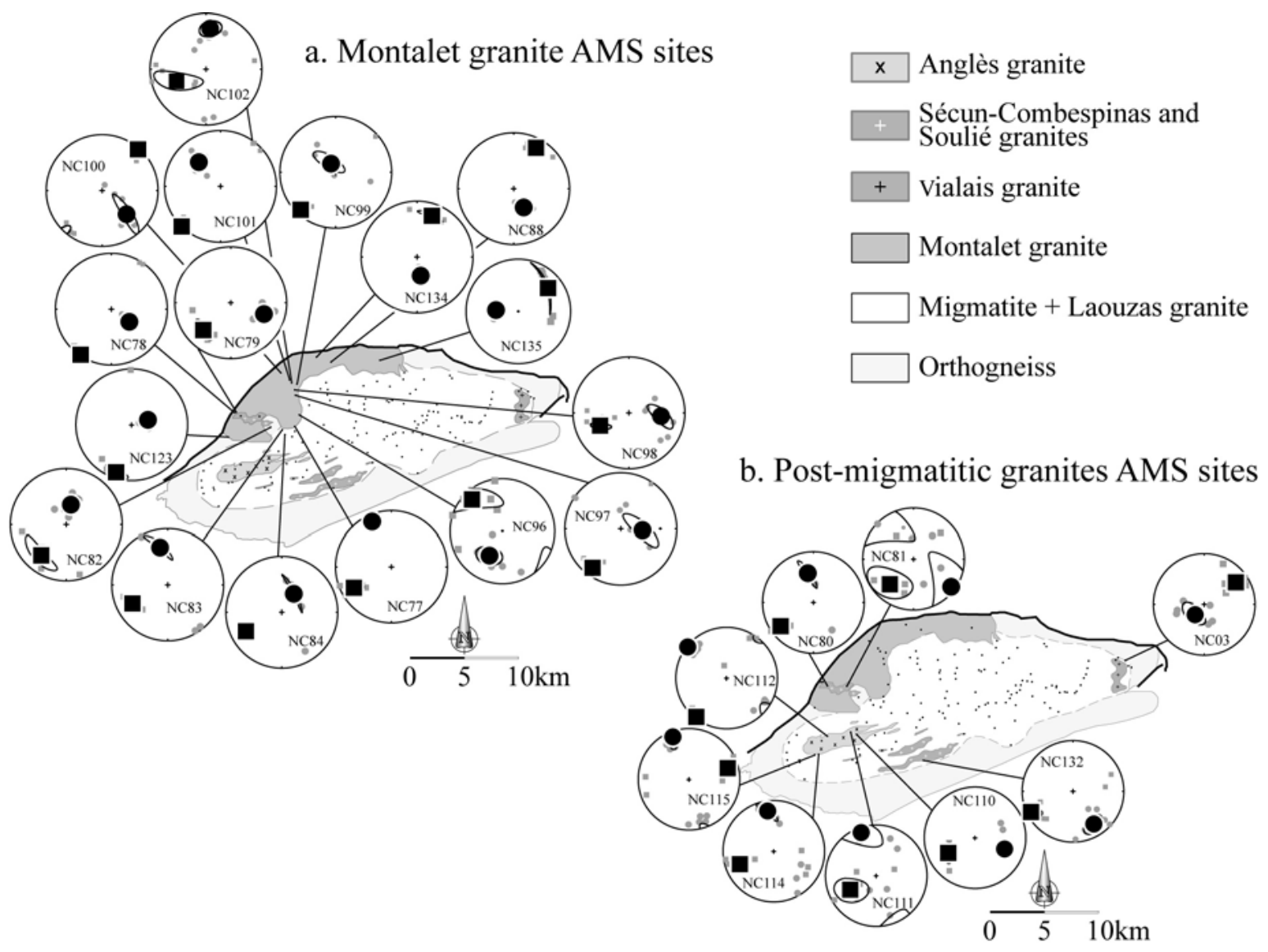

Figure 8 


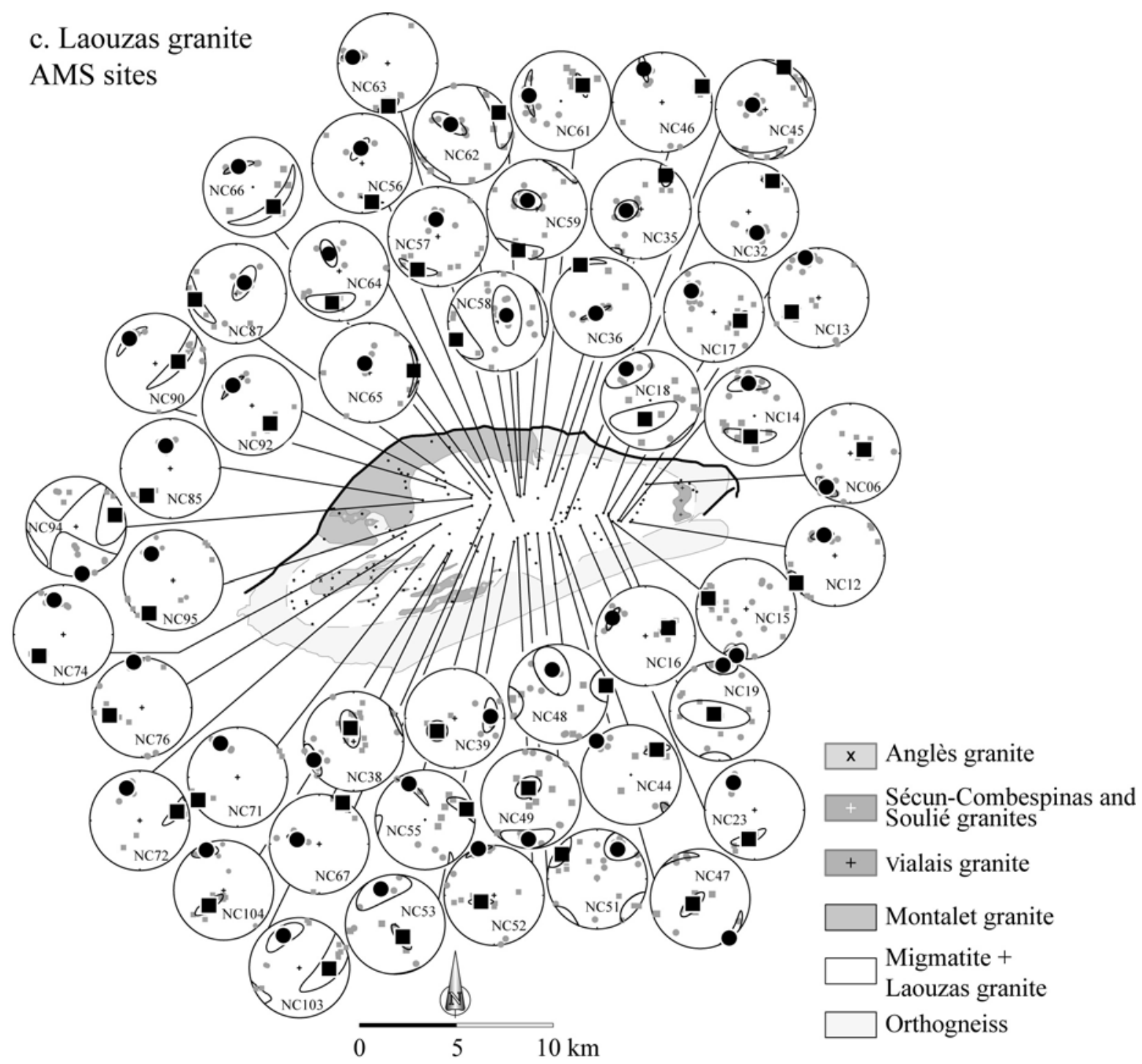

Figure 8 (suite). 
d. Migmatitic orthogneiss AMS sites

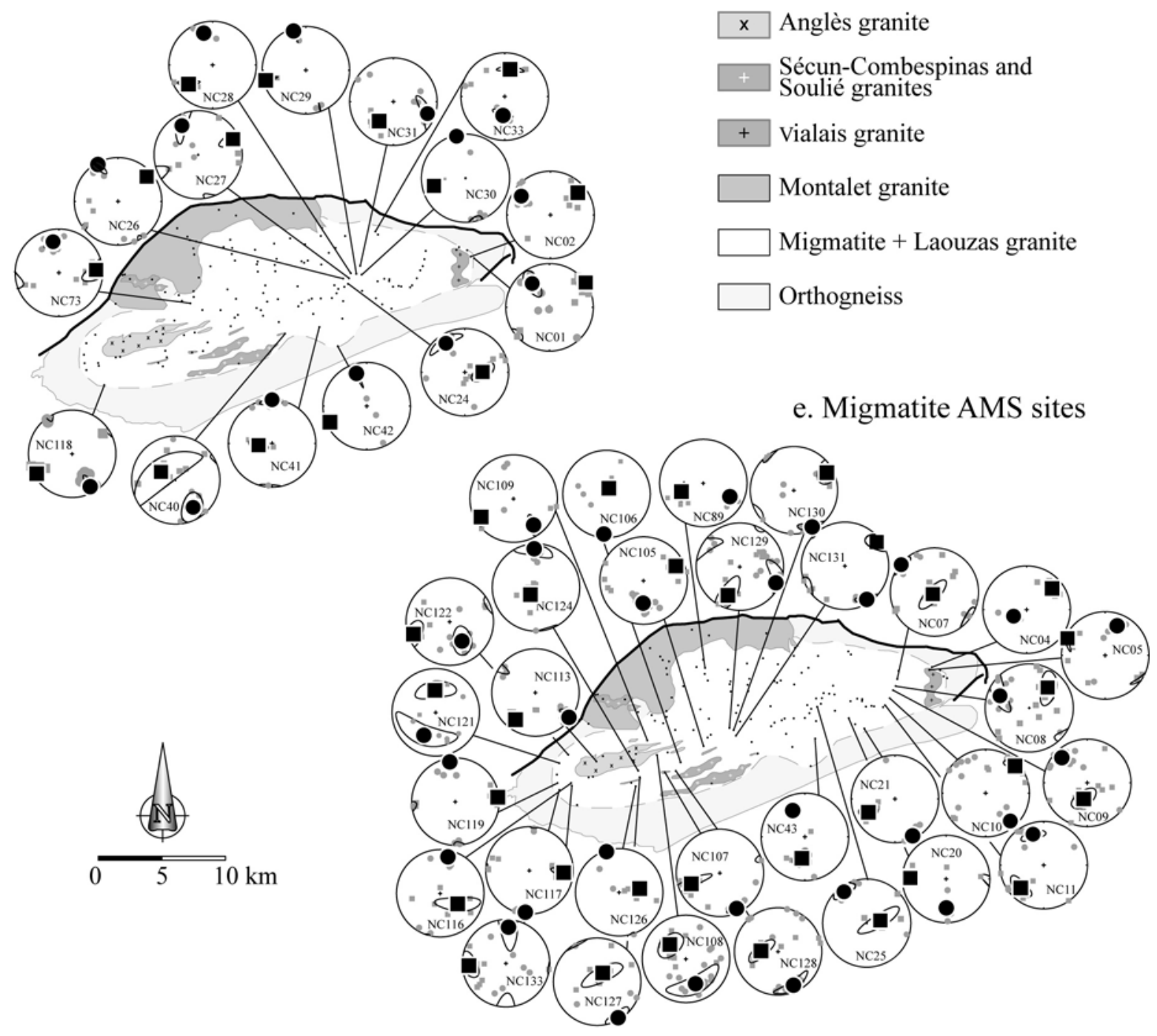

Figure 8 (suite). 


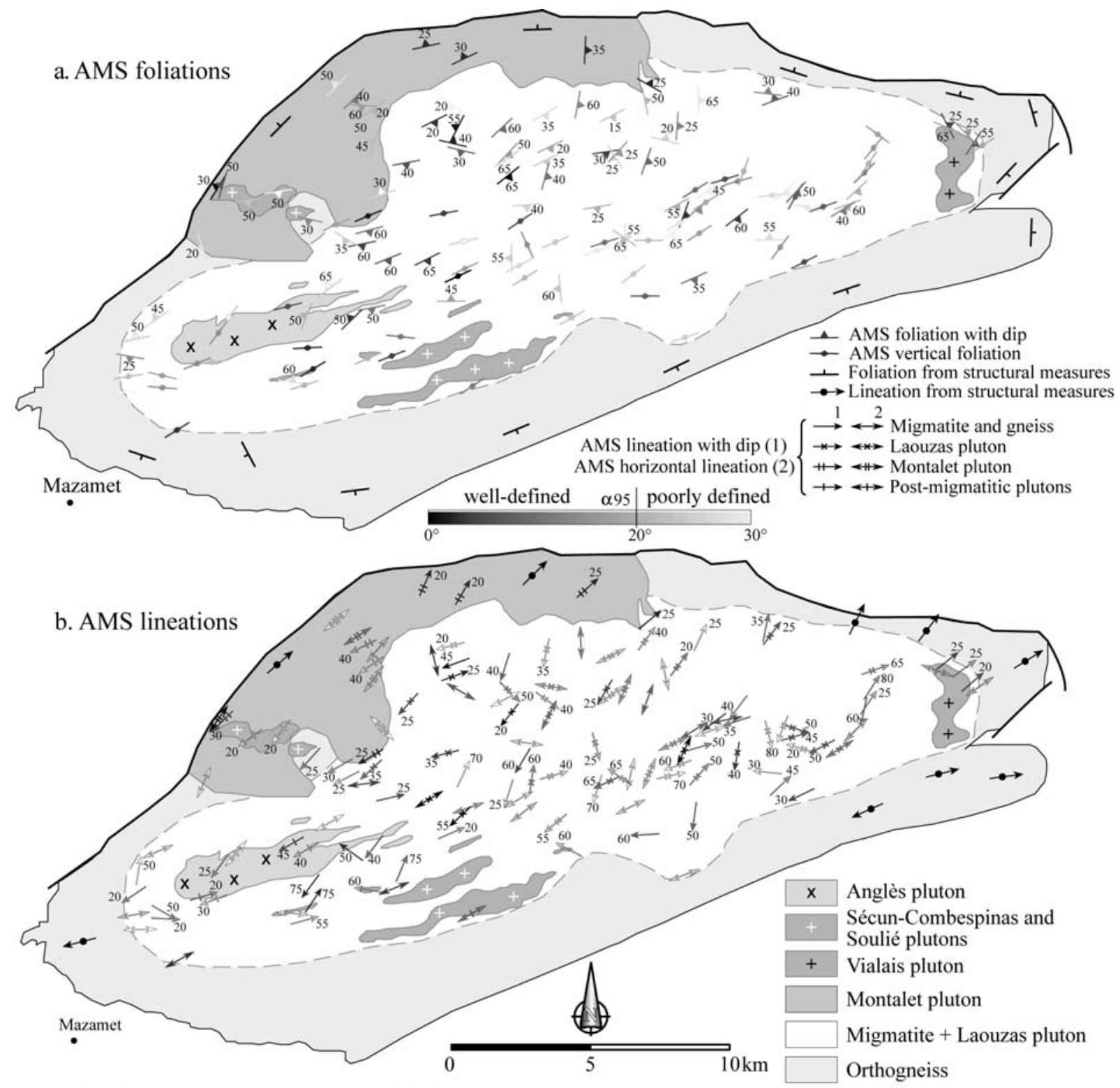

c. Density contours of individual AMS axes

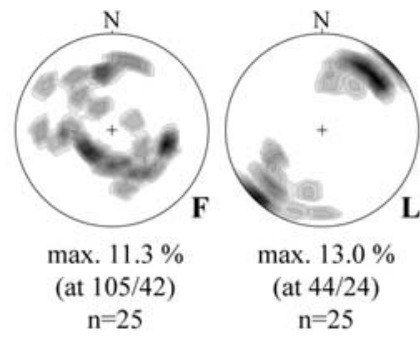

Northern part

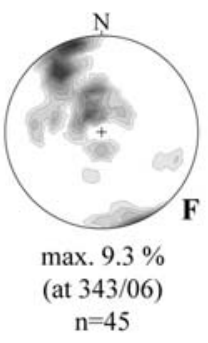

Centre part

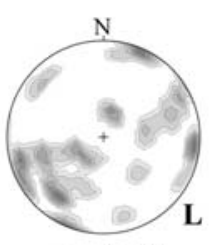

$\max .6 .2 \%$

(at 218/24)

$\mathrm{n}=45$

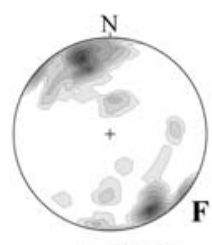

$\max .8 .5 \%$

(at 152/12)

$\mathrm{n}=65$

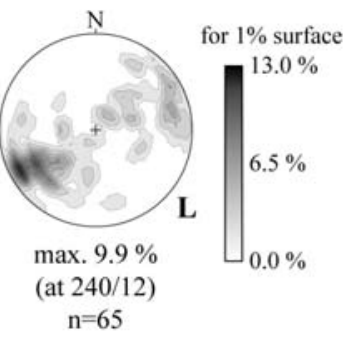

Southern part

Figure 9 


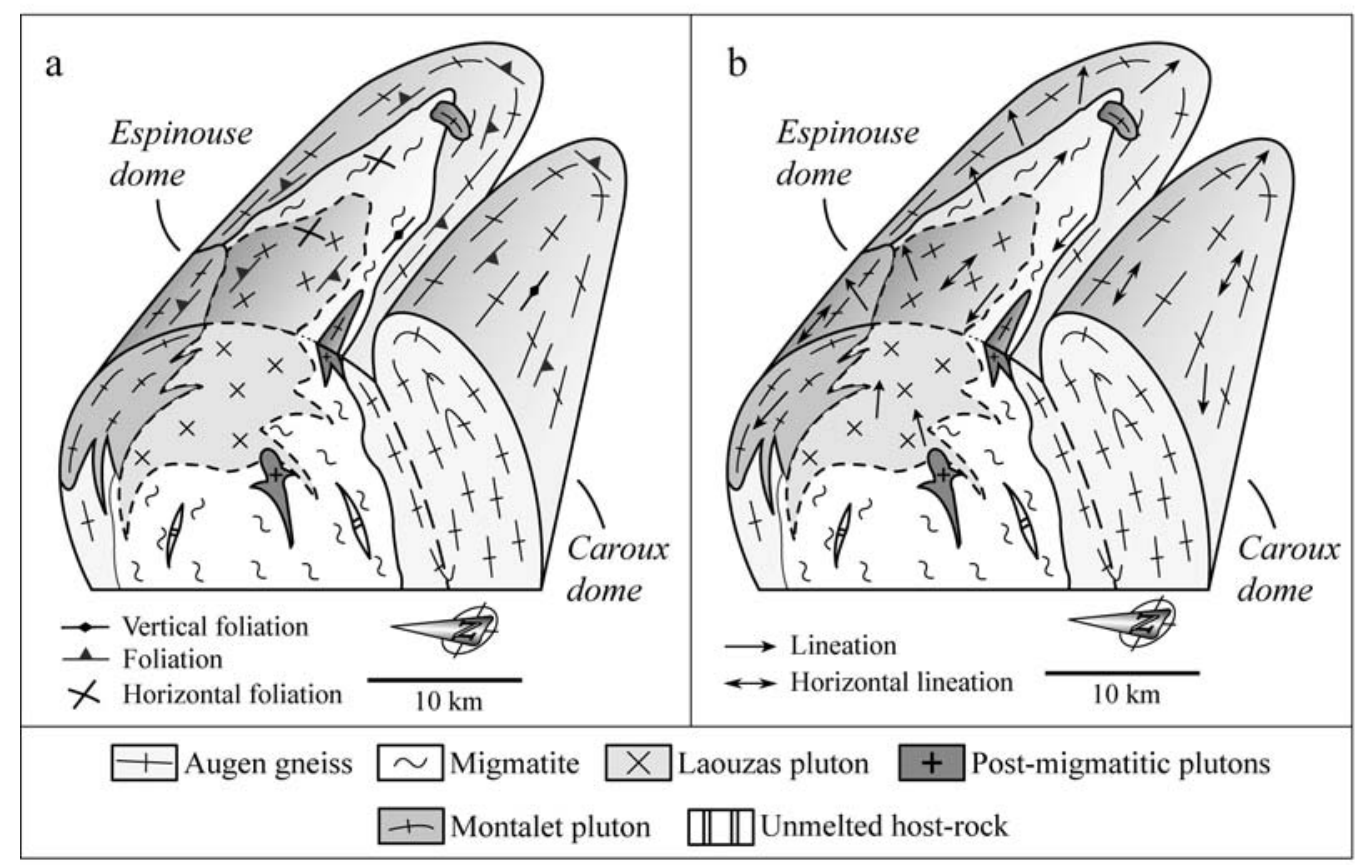

Figure 10

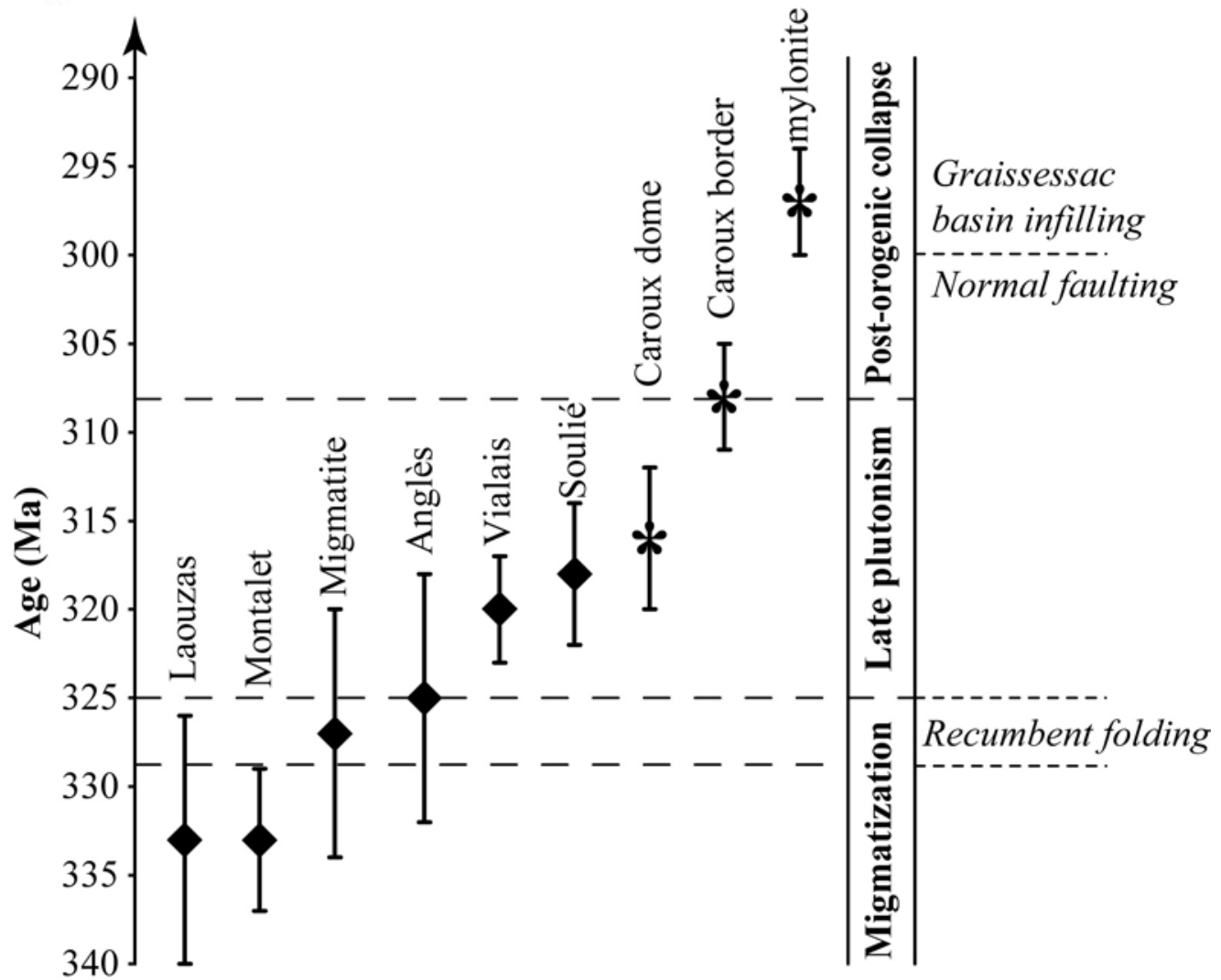

Chemical U-Th-Pb age on Monazite (Bé Mézème, 2005; Charles et al., 2008)

* Radiometric Ar-Ar age on Biotite and Muscovite (Maluski et al., 1991)

Figure 11 
a. Diapirism (Schuiling, 1960; Faure and Cottereau, 1988)

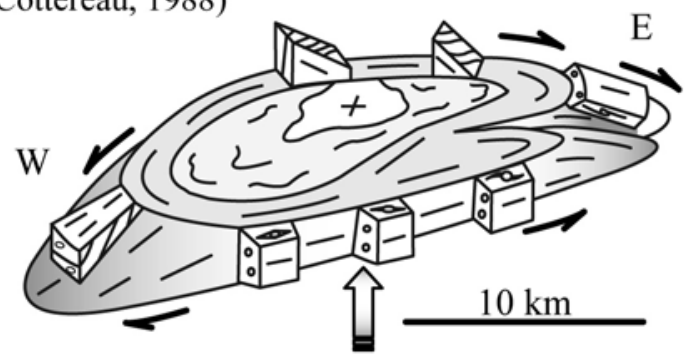

b. Metamorphic Core Complex (Van Den Driessche and Brun, 1992)

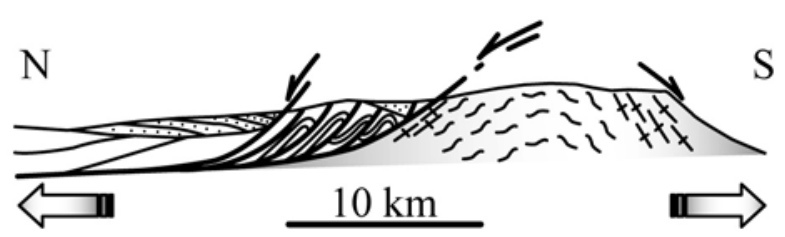

c. Anticlinal stacking (Arthaud, 1970, Mattauer et al., 1996, Matte et al., 1998)

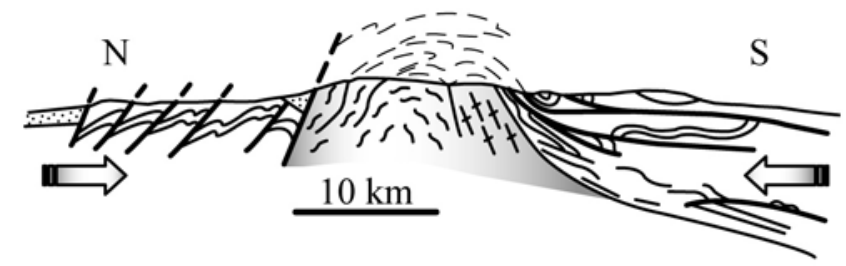

Figure 12 


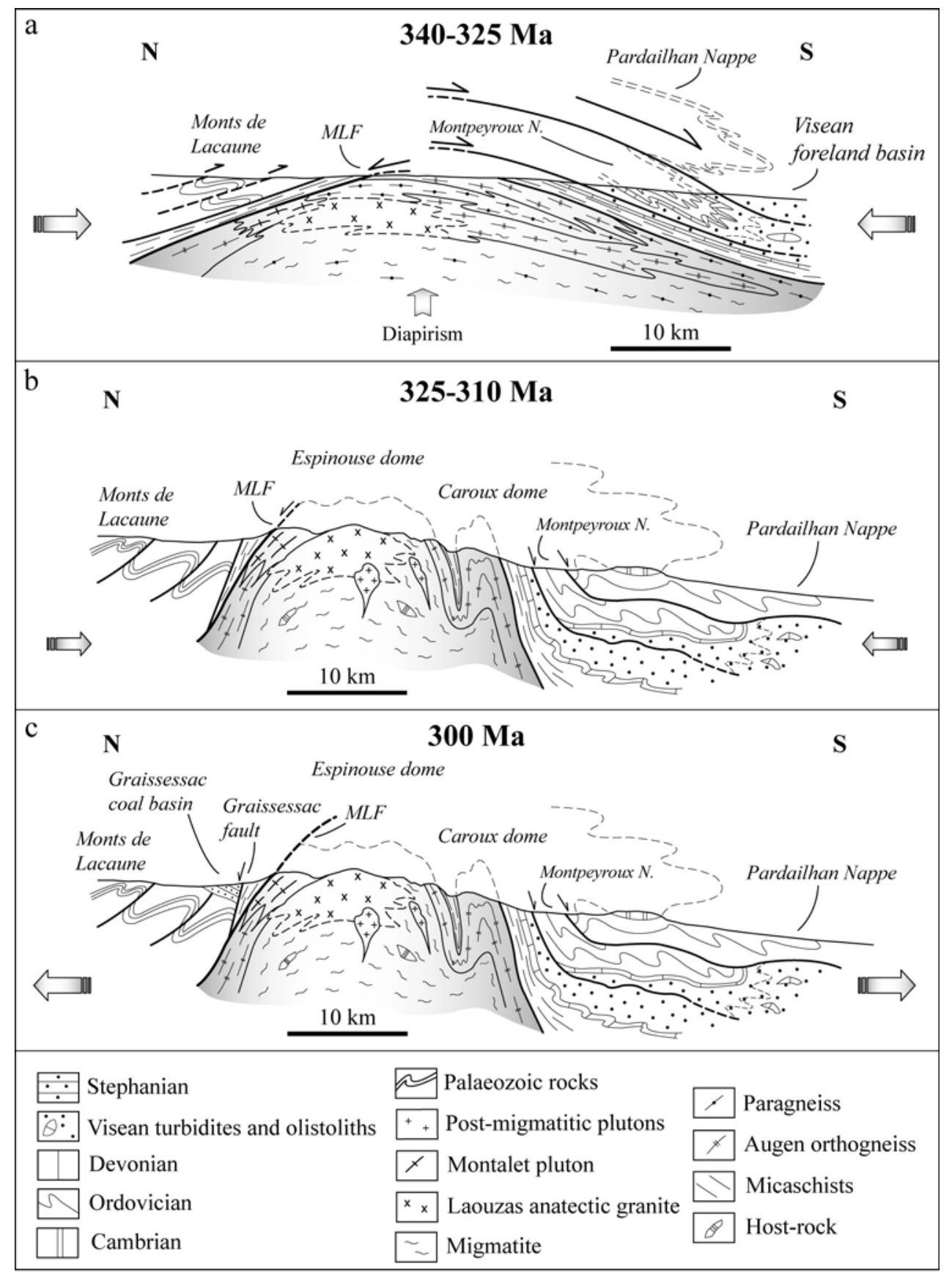

Figure 13 


\begin{tabular}{|c|c|c|c|c|c|c|c|c|c|c|c|c|c|c|c|}
\hline \multirow[t]{2}{*}{ Site } & \multicolumn{2}{|c|}{ Coordinates } & \multirow[t]{2}{*}{ Lithology } & \multirow[t]{2}{*}{$\mathbf{n}$} & \multirow{2}{*}{$\begin{array}{c}\mathrm{Km} \\
\left(10^{-6}\right. \\
\mathrm{SI})\end{array}$} & \multirow[t]{2}{*}{$\mathbf{P}_{\mathbf{j}}$} & $\mathbf{T}$ & & & & & & & & \\
\hline & $\begin{array}{c}\text { Latitude } \\
\left({ }^{\circ} \mathrm{N}\right)\end{array}$ & $\begin{array}{c}\text { Longitude } \\
\left({ }^{\circ} \mathrm{E}\right)\end{array}$ & & & & & & $\operatorname{Dec}\left({ }^{\circ}\right)$ & Inc $\left(^{\circ}\right)$ & $\alpha_{95 \min }$ & $\alpha_{95 \max }$ & $\operatorname{Dec}\left({ }^{\circ}\right)$ & Inc $\left(^{\circ}\right)$ & $\alpha_{95 \min }$ & $\alpha_{95 \max }$ \\
\hline NC01 & 2.976 & 43.637 & $\mathrm{OM}$ & 8 & 60.2 & 1.130 & 0.142 & 55.0 & 4.7 & 10.0 & 16.7 & 322.1 & 32.5 & 10.9 & 30.7 \\
\hline NC02 & 2.971 & 43.638 & $\mathrm{OM}$ & 9 & 76.4 & 1.223 & 0.686 & 45.0 & 28.3 & 5.6 & 15.1 & 299.8 & 25.9 & 5.9 & 17.3 \\
\hline NC03 & 2.967 & 43.644 & GV & 6 & 10.3 & 1.121 & 0.323 & 49.4 & 30.9 & 10.8 & 16.1 & 243.9 & 58.3 & 11.9 & 21.8 \\
\hline NC04 & 2.956 & 43.648 & M & 7 & 89.9 & 1.138 & 0.419 & 50.2 & 25.3 & 5.0 & 15.0 & 239.9 & 64.4 & 5.3 & 11.5 \\
\hline NC05 & 2.952 & 43.645 & M & 5 & 62.2 & 1.081 & 0.671 & 293.9 & 0.9 & 3.5 & 25.6 & 24.4 & 27.0 & 2.1 & 13.3 \\
\hline NC06 & 2.911 & 43.644 & GL & 11 & 100.0 & 1.025 & -0.039 & 76.4 & 64.9 & 12.5 & 16.3 & 217.3 & 19.9 & 11.3 & 24.0 \\
\hline NC07 & 2.909 & 43.636 & M & 9 & 85.3 & 1.117 & 0.816 & 214.8 & 84.2 & 11.9 & 35.2 & 308.2 & 0.3 & 11.2 & 18.0 \\
\hline NC08 & 2.907 & 43.629 & M & 11 & 350.0 & 1.290 & 0.337 & 44.0 & 36.5 & 14.1 & 34.6 & 296.5 & 22.1 & 12.3 & 42.4 \\
\hline NC09 & 2.904 & 43.625 & M & 10 & 90.9 & 1.038 & 0.858 & 211.0 & 30.9 & 4.4 & 17.5 & 325.2 & 34.5 & 3.0 & 17.0 \\
\hline NC10 & 2.899 & 43.617 & M & 10 & 73.1 & 1.001 & 0.745 & 46.5 & 5.5 & 2.8 & 9.6 & 136.6 & 1.1 & 1.4 & 5.5 \\
\hline NC11 & 2.893 & 43.611 & $\mathrm{M}$ & 9 & 103.0 & 1.032 & 0.393 & 238.6 & 6.0 & 1.5 & 7.5 & 330.0 & 13.3 & 0.9 & 10.0 \\
\hline NC12 & 2.890 & 43.609 & GL & 7 & 77.1 & 1.052 & 0.511 & 230.4 & 2.8 & 7.7 & 17.2 & 323.5 & 47.7 & 6.1 & 14.8 \\
\hline NC13 & 2.878 & 43.610 & GL & 10 & 257.0 & 1.123 & 0.522 & 238.8 & 35.6 & 11.9 & 23.8 & 339.1 & 14.0 & 9.5 & 19.5 \\
\hline NC14 & 2.874 & 43.610 & GL & 10 & 89.5 & 1.100 & 0.092 & 192.7 & 54.8 & 11.5 & 41.9 & 349.7 & 33.0 & 13.4 & 31.3 \\
\hline NC15 & 2.867 & 43.609 & GL & 10 & 100.0 & 1.057 & 0.484 & 285.4 & 22.3 & 10.2 & 19.5 & 193.2 & 2.6 & 12.6 & 31.8 \\
\hline NC16 & 2.862 & 43.615 & GL & 5 & 251.0 & 1.126 & 0.643 & 71.4 & 56.5 & 6.5 & 14.8 & 297.6 & 24.6 & 6.6 & 17.4 \\
\hline NC17 & 2.862 & 43.617 & GL & 11 & 208.0 & 1.085 & 0.478 & 105.4 & 45.2 & 8.2 & 17.4 & 313.3 & 38.1 & 6.0 & 15.8 \\
\hline NC18 & 2.855 & 43.617 & GL & 7 & 263.0 & 1.055 & 0.684 & 196.9 & 56.5 & 21.5 & 58.9 & 324.1 & 21.8 & 28.2 & 35.6 \\
\hline NC19 & 2.846 & 43.615 & GL & 8 & 262.0 & 1.047 & 0.553 & 251.4 & 81.0 & 21.6 & 60.8 & 4.6 & 3.6 & 19.0 & 22.3 \\
\hline NC20 & 2.844 & 43.598 & $\mathrm{M} / \mathrm{G}$ & 6 & 210.0 & 1.095 & 0.333 & 270.4 & 2.6 & 6.3 & 25.2 & 178.6 & 34.4 & 7.8 & 10.9 \\
\hline NC21 & 2.865 & 43.588 & $\mathrm{M} / \mathrm{G}$ & 8 & 147.0 & 1.073 & 0.62 & 249.3 & 39.3 & 3.5 & 15.8 & 148.5 & 12.9 & 3.5 & 8.3 \\
\hline NC22 & 2.852 & 43.592 & G & 18 & 139.0 & 1.404 & 0.17 & 46.2 & 44.6 & 7.9 & 22.3 & 306.1 & 1.1 & 13.3 & 14.8 \\
\hline NC23 & 2.825 & 43.605 & GL & 5 & 138.0 & 1.056 & 0.669 & 198.5 & 36.0 & 4.1 & 27.5 & 315.3 & 31.8 & 2.3 & 7.6 \\
\hline NC24 & 2.806 & 43.612 & OM & 9 & 138.0 & 1.068 & 0.158 & 99.3 & 72.9 & 12.1 & 24.6 & 326.6 & 11.8 & 9.3 & 27.9 \\
\hline NC25 & 2.801 & 43.610 & M & 7 & 287.0 & 1.118 & 0.704 & 79.2 & 65.3 & 11.4 & 45.9 & 324.8 & 10.7 & 11.8 & 18.2 \\
\hline NC26 & 2.800 & 43.618 & OM & 5 & 104.0 & 1.093 & 0.626 & 53.9 & 1.7 & 3.8 & 13.7 & 323.5 & 14.0 & 4.2 & 19.5 \\
\hline NC27 & 2.808 & 43.618 & $\mathrm{OM}$ & 5 & 109.0 & 1.078 & 0.506 & 65.7 & 9.5 & 9.5 & 37.4 & 331.9 & 21.8 & 9.1 & 37.9 \\
\hline NC28 & 2.811 & 43.621 & OM & 6 & 88.2 & 1.083 & 0.349 & 233.5 & 28.9 & 3.7 & 16.5 & 340.6 & 28.1 & 3.5 & 10.7 \\
\hline NC29 & 2.818 & 43.622 & $\mathrm{OM}$ & 5 & 85.0 & 1.045 & -0.21 & 253.9 & 8.3 & 2.9 & 7.8 & 345.0 & 7.5 & 0.7 & 27.3 \\
\hline NC30 & 2.825 & 43.621 & OM & 7 & 100.0 & 1.072 & 0.117 & 256.1 & 26.6 & 6.8 & 10.6 & 347.4 & 2.6 & 8.5 & 14.7 \\
\hline NC31 & 2.826 & 43.628 & $\mathrm{OM} / \mathrm{G}$ & 9 & 72.2 & 1.062 & -0.232 & 215.4 & 40.3 & 6.0 & 12.6 & 106.0 & 21.3 & 8.3 & 33.3 \\
\hline NC32 & 2.847 & 43.660 & GL & 9 & 187.0 & 1.087 & 0.177 & 35.1 & 25.7 & 4.5 & 9.5 & 172.9 & 57.0 & 4.7 & 22.4 \\
\hline NC33 & 2.844 & 43.663 & $\mathrm{OM}$ & 7 & 644.0 & 1.174 & 0.231 & 16.2 & 34.8 & 5.4 & 14.3 & 194.3 & 55.2 & 2.9 & 7.5 \\
\hline NC34 & 2.803 & 43.659 & CB & 7 & 497.0 & 1.091 & -0.205 & 25.2 & 24.5 & 8.8 & 21.0 & 268.8 & 26.3 & 11.5 & 35.7 \\
\hline NC35 & 2.790 & 43.648 & GL & 9 & 187.0 & 1.051 & 0.194 & 33.4 & 12.6 & 9.1 & 23.4 & 270.1 & 67.9 & 15.4 & 20.7 \\
\hline NC36 & 2.781 & 43.643 & M/GL & 6 & 35.0 & 1.124 & 0.536 & 342.7 & 6.2 & 4.8 & 24.5 & 223.7 & 77.4 & 3.2 & 26.6 \\
\hline NC37 & 2.771 & 43.631 & $\mathrm{OM}$ & 7 & 71.9 & 1.039 & 0.15 & 18.9 & 2.0 & 6.1 & 23.9 & 289.5 & 41.5 & 6.3 & 15.1 \\
\hline NC38 & 2.698 & 43.595 & GL & 11 & 176.0 & 1.116 & 0.217 & 353.9 & 69.6 & 15.0 & 32.0 & 245.9 & 6.6 & 15.6 & 21.3 \\
\hline NC39 & 2.713 & 43.576 & GL & 6 & 181.0 & 1.134 & -0.022 & 231.2 & 58.9 & 16.2 & 17.5 & 88.8 & 25.5 & 12.8 & 24.6 \\
\hline NC40 & 2.721 & 43.564 & $\mathrm{OM}$ & 8 & 339.0 & 1.173 & 0.878 & 298.5 & 59.7 & 25.7 & 82.0 & 149.0 & 26.8 & 17.8 & 30.1 \\
\hline NC41 & 2.768 & 43.571 & $\mathrm{OM}$ & 6 & 136.0 & 1.067 & 0.316 & 264.9 & 66.7 & 8.8 & 19.0 & 0.1 & 2.2 & 7.2 & 14.9 \\
\hline NC42 & 2.792 & 43.552 & $\mathrm{OM}$ & 5 & 248.0 & 1.171 & -0.232 & 247.2 & 9.0 & 1.8 & 5.0 & 340.2 & 18.0 & 1.8 & 30.3 \\
\hline NC43 & 2.799 & 43.579 & $\mathrm{M}$ & 5 & 232.0 & 1.174 & 0.64 & 188.9 & 44.5 & 3.9 & 20.0 & 335.4 & 40.3 & 3.8 & 7.6 \\
\hline NC44 & 2.803 & 43.598 & GL & 6 & 77.6 & 1.050 & 0.474 & 45.4 & 26.8 & 5.8 & 23.9 & 314.6 & 1.6 & 5.1 & 20.1 \\
\hline NC45 & 2.793 & 43.607 & GL & 12 & 106.0 & 1.035 & 0.789 & 21.6 & 1.0 & 9.5 & 53.1 & 288.9 & 69.0 & 9.0 & 11.2 \\
\hline NC46 & 2.788 & 43.611 & GL & 7 & 63.8 & 1.040 & -0.257 & 71.8 & 16.3 & 4.9 & 11.5 & 334.5 & 23.4 & 4.5 & 26.5 \\
\hline NC47 & 2.791 & 43.603 & GL & 6 & 96.0 & 1.042 & 0.098 & 233.8 & 74.0 & 9.5 & 26.6 & 142.6 & 0.3 & 6.9 & 38.9 \\
\hline NC48 & 2.785 & 43.599 & GL & 7 & 117.0 & 1.039 & 0.033 & 79.8 & 2.6 & 19.4 & 31.7 & 347.0 & 47.2 & 24.6 & 46.1 \\
\hline NC49 & 2.770 & 43.598 & GL & 9 & 28.4 & 1.085 & 0.125 & 346.3 & 70.7 & 16.2 & 22.5 & 184.0 & 18.4 & 18.5 & 37.3 \\
\hline NC50 & 2.758 & 43.598 & LeucoG & 7 & 20.2 & 1.125 & -0.005 & 11.7 & 14.9 & 24.6 & 30.6 & 268.4 & 33.7 & 16.3 & 25.8 \\
\hline NC51 & 2.754 & 43.597 & GL & 11 & 173.0 & 1.141 & 0.015 & 306.7 & 0.1 & 21.4 & 26.6 & 36.8 & 16.4 & 20.4 & 33.7 \\
\hline NC52 & 2.744 & 43.594 & GL & 10 & 88.8 & 1.053 & 0.188 & 205.6 & 80.9 & 9.1 & 16.3 & 325.7 & 4.6 & 7.9 & 45.4 \\
\hline NC53 & 2.740 & 43.591 & GL & 5 & 311.0 & 1.037 & -0.128 & 154.5 & 66.6 & 8.1 & 25.5 & 338.4 & 23.3 & 24.5 & 42.4 \\
\hline NC54 & 2.760 & 43.583 & G & 10 & 51.8 & 1.077 & 0.309 & 245.8 & 14.3 & 8.4 & 24.6 & 140.4 & 23.8 & 17.3 & 19.5 \\
\hline NC55 & 2.712 & 43.598 & GL & 7 & 547.0 & 1.180 & 0.167 & 74.2 & 14.6 & 10.9 & 34.9 & 337.2 & 25.3 & 4.4 & 46.9 \\
\hline NC56 & 2.739 & 43.610 & GL & 6 & 113.0 & 1.045 & 0.103 & 170.7 & 25.5 & 2.5 & 11.7 & 349.4 & 64.5 & 4.8 & 8.9 \\
\hline NC57 & 2.744 & 43.635 & GL & 10 & 54.1 & 1.065 & 0.784 & 217.5 & 20.4 & 11.1 & 43.1 & 346.4 & 59.4 & 8.4 & 11.2 \\
\hline NC58 & 2.748 & 43.633 & GL & 10 & 56.4 & 1.045 & 0.036 & 248.1 & 14.3 & 22.5 & 43.7 & 73.9 & 75.6 & 23.5 & 50.6 \\
\hline NC59 & 2.753 & 43.635 & GL & 8 & 50.5 & 1.063 & 0.514 & 204.1 & 8.9 & 15.7 & 34.2 & 312.2 & 63.4 & 15.6 & 24.2 \\
\hline NC60 & 2.772 & 43.667 & $\mathrm{OM}$ & 11 & 126.0 & 1.071 & 0.398 & 32.9 & 24.7 & 3.6 & 11.5 & 209.5 & 65.5 & 4.9 & 6.7 \\
\hline NC61 & 2.770 & 43.659 & GL & 10 & 570.0 & 1.168 & -0.272 & 53.1 & 45.1 & 5.9 & 19.6 & 283.2 & 32.6 & 5.9 & 35.4 \\
\hline NC62 & 2.749 & 43.651 & GL & 9 & 81.3 & 1.043 & 0.338 & 60.7 & 11.8 & 20.2 & 48.6 & 309.1 & 60.4 & 11.3 & 33.0 \\
\hline NC63 & 2.729 & 43.657 & M/GL & 7 & 276.0 & 1.113 & 0.592 & 187.8 & 6.5 & 4.8 & 25.2 & 281.5 & 29.9 & 7.3 & 19.5 \\
\hline NC64 & 2.708 & 43.652 & GL & 7 & 21.5 & 1.046 & 0.241 & 196.7 & 30.3 & 16.2 & 37.8 & 0.5 & 58.7 & 11.3 & 24.2 \\
\hline NC65 & 2.711 & 43.637 & GL & 7 & 35.8 & 1.053 & 0.712 & 87.3 & 6.6 & 4.3 & 33.1 & 328.6 & 76.5 & 2.6 & 11.1 \\
\hline NC66 & 2.708 & 43.631 & GL & 5 & 135.0 & 1.056 & 0.899 & 135.5 & 42.1 & 10.0 & 73.0 & 324.3 & 47.5 & 5.1 & 25.0 \\
\hline NC67 & 2.709 & 43.625 & GL & 6 & 75.9 & 1.032 & 0.411 & 26.9 & 7.6 & 2.5 & 23.7 & 285.8 & 55.6 & 4.7 & 14.1 \\
\hline NC68 & 2.695 & 43.611 & Paragneiss & 6 & 1570.0 & 1.367 & 0.125 & 97.1 & 9.2 & 10.8 & 30.5 & 354.8 & 47.2 & 15.3 & 24.6 \\
\hline
\end{tabular}




\begin{tabular}{|c|c|c|c|c|c|c|c|c|c|c|c|c|c|c|c|}
\hline NC69 & 2.693 & 43.604 & G & 8 & 5330.0 & 1.113 & -0.173 & 211.0 & 60.7 & 4.7 & 11.5 & 326.5 & 16.5 & 2.6 & 15.7 \\
\hline NC70 & 2.656 & 43.598 & LeucoG & 6 & 22.1 & 1.025 & 0.025 & 25.3 & 69.9 & 20.9 & 35.2 & 166.1 & 17.0 & 26.3 & 32.4 \\
\hline NC71 & 2.635 & 43.587 & GL & 9 & 1200.0 & 1.049 & 0.554 & 235.0 & 5.5 & 5.4 & 9.4 & 328.2 & 29.6 & 4.4 & 9.7 \\
\hline NC72 & 2.611 & 43.588 & OM/GL & 6 & 71.0 & 1.124 & 0.875 & 91.3 & 33.6 & 7.2 & 33.7 & 335.6 & 33.1 & 6.1 & 20.2 \\
\hline NC73 & 2.595 & 43.594 & $\mathrm{OM} / \mathrm{G}$ & 9 & 111.0 & 1.100 & 0.599 & 85.9 & 13.9 & 11.7 & 34.0 & 347.8 & 29.4 & 8.7 & 14.6 \\
\hline NC74 & 2.599 & 43.600 & GL & 9 & 107.0 & 1.050 & 0.318 & 230.7 & 35.7 & 5.6 & 10.2 & 347.8 & 32.4 & 5.3 & 12.3 \\
\hline NC75 & 2.600 & 43.566 & G & 9 & 129.0 & 1.049 & 0.408 & 217.4 & 38.1 & 1.7 & 15.0 & 349.5 & 41.2 & 9.4 & 13.8 \\
\hline NC76 & 2.645 & 43.608 & GL & 12 & 90.6 & 1.036 & 0.469 & 254.2 & 41.4 & 5.5 & 20.4 & 350.0 & 6.5 & 7.8 & 16.4 \\
\hline NC77 & 2.599 & 43.606 & GM & 6 & 28.2 & 1.083 & -0.055 & 239.7 & 24.7 & 3.6 & 19.9 & 336.2 & 13.7 & 3.7 & 8.4 \\
\hline NC78 & 2.504 & 43.622 & GM & 6 & 73.6 & 1.134 & 0.216 & 214.4 & 2.9 & 2.4 & 7.8 & 122.8 & 58.0 & 2.3 & 5.9 \\
\hline NC79 & 2.507 & 43.622 & GM & 5 & 91.4 & 1.149 & 0.452 & 225.9 & 31.7 & 6.7 & 20.1 & 105.1 & 39.6 & 7.2 & 12.2 \\
\hline NC80 & 2.514 & 43.585 & GSC & 5 & 28.6 & 1.044 & 0.224 & 236.8 & 23.5 & 4.5 & 12.7 & 349.5 & 41.6 & 4.1 & 20.9 \\
\hline NC81 & 2.543 & 43.618 & GSC & 5 & 32.5 & 1.057 & -0.088 & 217.8 & 22.1 & 27.5 & 36.9 & 350.4 & 39.8 & 19.3 & 40.6 \\
\hline NC82 & 2.561 & 43.605 & GM & 5 & 84.4 & 1.066 & 0.585 & 223.4 & 30.8 & 8.2 & 27.4 & 16.2 & 56.2 & 8.8 & 15.1 \\
\hline NC83 & 2.579 & 43.602 & GM & 5 & 102.0 & 1.034 & -0.375 & 240.6 & 28.9 & 1.1 & 12.4 & 348.6 & 29.3 & 4.3 & 30.6 \\
\hline NC84 & 2.583 & 43.597 & GM/LeucoG & 5 & 37.0 & 1.036 & 0.258 & 245.9 & 19.9 & 0.3 & 3.0 & 148.3 & 20.0 & 0.6 & 1.0 \\
\hline NC85 & 2.622 & 43.630 & GL & 5 & 128.0 & 1.080 & 0.338 & 222.1 & 22.4 & 1.3 & 13.6 & 345.1 & 52.8 & 4.2 & 9.9 \\
\hline NC86 & 2.640 & 43.649 & LeucoG & 4 & 34.8 & 1.073 & 0.017 & 165.9 & 17.4 & 1.2 & 8.4 & 333.6 & 72.6 & 4.1 & 9.6 \\
\hline NC87 & 2.649 & 43.656 & GL & 5 & 63.3 & 1.076 & 0.195 & 256.3 & 19.1 & 10.8 & 45.2 & 36.3 & 67.9 & 13.6 & 35.9 \\
\hline NC88 & 2.656 & 43.680 & GM & 8 & 77.1 & 1.117 & 0.260 & 28.0 & 19.0 & 4.0 & 10.6 & 154.4 & 59.8 & 3.8 & 8.8 \\
\hline NC89 & 2.651 & 43.648 & $\mathrm{G} / \mathrm{M}$ & 8 & 30.3 & 1.334 & 0.181 & 249.9 & 46.6 & 2.4 & 17.2 & 117.2 & 32.6 & 2.5 & 6.4 \\
\hline NC90 & 2.651 & 43.642 & GL & 9 & 412.0 & 1.070 & 0.380 & 66.9 & 25.5 & 5.0 & 8.0 & 193.4 & 51.3 & 3.9 & 8.3 \\
\hline NC91 & 2.655 & 43.636 & GM & 10 & 62.5 & 1.052 & 0.409 & 119.1 & 8.9 & 8.1 & 17.0 & 13.4 & 60.0 & 9.6 & 11.7 \\
\hline NC92 & 2.685 & 43.635 & GL & 7 & 8.9 & 1.055 & 0.421 & 134.9 & 47.8 & 4.1 & 16.3 & 313.4 & 42.2 & 4.1 & 23.9 \\
\hline NC93 & 2.682 & 43.646 & $\mathrm{G}$ & 11 & 80.9 & 1.021 & 0.233 & 197.7 & 41.8 & 9.8 & 12.2 & 316.9 & 28.6 & 8.4 & 14.0 \\
\hline NC94 & 2.684 & 43.632 & GL & 7 & 101.0 & 1.038 & -0.573 & 61.2 & 10.2 & 6.0 & 20.1 & 326.1 & 26.1 & 8.7 & 58.8 \\
\hline NC95 & 2.685 & 43.625 & GL & 10 & 162.0 & 1.287 & 0.471 & 218.5 & 21.0 & 2.1 & 13.8 & 321.3 & 29.8 & 1.3 & 2.3 \\
\hline NC96 & 2.606 & 43.619 & GM & 8 & 50.4 & 1.027 & 0.447 & 319.3 & 19.4 & 15.4 & 44.3 & 208.5 & 45.3 & 15.0 & 19.7 \\
\hline NC97 & 2.600 & 43.642 & GM & 8 & 105.0 & 1.073 & -0.634 & 217.7 & 14.8 & 5.9 & 12.9 & 99.4 & 60.9 & 10.6 & 37.4 \\
\hline NC98 & 2.599 & 43.648 & GM & 8 & 170.0 & 1.090 & 0.111 & 240.4 & 41.5 & 4.6 & 17.1 & 95.1 & 42.9 & 9.2 & 26.8 \\
\hline NC99 & 2.603 & 43.654 & GM & 6 & 144.0 & 1.051 & -0.428 & 222.5 & 5.0 & 6.5 & 11.6 & 325.4 & 68.4 & 7.1 & 25.2 \\
\hline NC100 & 2.577 & 43.667 & GM & 6 & 23.1 & 1.105 & -0.532 & 224.8 & 1.6 & 4.4 & 14.2 & 133.5 & 39.4 & 6.8 & 40.3 \\
\hline NC101 & 2.591 & 43.659 & GM & 7 & 152.0 & 1.041 & 0.052 & 224.0 & 1.4 & 5.5 & 8.0 & 315.7 & 50.0 & 6.6 & 17.9 \\
\hline NC102 & 2.594 & 43.656 & GM & 9 & 150.0 & 1.058 & 0.415 & 245.4 & 41.1 & 12.9 & 41.5 & 4.0 & 28.8 & 12.7 & 16.7 \\
\hline NC103 & 2.658 & 43.583 & GL & 7 & 141.0 & 1.060 & 0.513 & 66.1 & 7.5 & 3.7 & 13.6 & 333.7 & 18.0 & 2.9 & 3.9 \\
\hline NC104 & 2.654 & 43.580 & GL & 11 & 192.0 & 1.055 & 0.438 & 225.7 & 55.3 & 8.1 & 29.3 & 334.9 & 12.8 & 11.3 & 18.5 \\
\hline NC105 & 2.649 & 43.572 & $\mathrm{M}$ & 14 & 126.0 & 1.138 & 0.689 & 66.5 & 20.1 & 8.6 & 12.7 & 180.0 & 47.5 & 7.7 & 16.5 \\
\hline NC106 & 2.618 & 43.556 & M & 5 & 50.3 & 1.056 & 0.026 & 22.8 & 76.8 & 0.8 & 15.7 & 185.3 & 12.6 & 3.7 & 12.4 \\
\hline NC107 & 2.611 & 43.548 & $\mathrm{M}$ & 8 & 265.0 & 1.266 & 0.793 & 251.5 & 15.0 & 6.0 & 17.8 & 158.3 & 12.0 & 5.6 & 8.3 \\
\hline NC108 & 2.586 & 43.563 & $\mathrm{M}$ & 12 & 149.0 & 1.052 & -0.188 & 305.6 & 51.4 & 17.0 & 24.0 & 135.7 & 38.2 & 16.8 & 48.9 \\
\hline NC109 & 2.573 & 43.577 & $\mathrm{M} / \mathrm{G}$ & 9 & 87.1 & 1.086 & 0.209 & 240.3 & 14.8 & 7.5 & 16.7 & 143.1 & 25.4 & 7.3 & 24.6 \\
\hline NC110 & 2.558 & 43.564 & GA & 9 & 196.0 & 1.055 & 0.161 & 241.0 & 38.8 & 7.8 & 16.4 & 111.3 & 38.4 & 6.6 & 12.1 \\
\hline NC111 & 2.549 & 43.567 & GA & 6 & 90.7 & 1.031 & -0.258 & 242.0 & 45.2 & 15.9 & 19.4 & 345.8 & 13.4 & 15.5 & 36.8 \\
\hline NC112 & 2.514 & 43.562 & GA & 9 & 169.0 & 1.069 & 0.322 & 218.7 & 2.4 & 7.5 & 12.3 & 308.8 & 0.3 & 7.9 & 19.4 \\
\hline NC113 & 2.505 & 43.557 & $\mathrm{M}$ & 11 & 225.0 & 1.070 & 0.273 & 216.1 & 25.0 & 7.0 & 12.6 & 124.9 & 2.6 & 5.8 & 28.8 \\
\hline NC114 & 2.500 & 43.542 & GA & 10 & 206.0 & 1.069 & 0.183 & 249.3 & 29.6 & 3.9 & 13.2 & 351.7 & 20.8 & 4.1 & 22.9 \\
\hline NC115 & 2.494 & 43.542 & GA & 11 & 195.0 & 1.063 & 0.125 & 74.1 & 20.8 & 5.6 & 15.9 & 339.4 & 12.2 & 6.4 & 23.2 \\
\hline NC116 & 2.471 & 43.536 & $\mathrm{M} / \mathrm{G}$ & 7 & 38.9 & 1.101 & 0.703 & 120.0 & 49.4 & 12.2 & 45.6 & 12.3 & 14.6 & 9.2 & 18.6 \\
\hline NC117 & 2.472 & 43.533 & $\mathrm{M}$ & 10 & 72.5 & 1.159 & 0.711 & 92.8 & 21.8 & 6.4 & 27.6 & 184.7 & 4.7 & 5.7 & 7.1 \\
\hline NC118 & 2.479 & 43.515 & $\mathrm{OM}$ & 7 & 124.0 & 1.170 & 0.053 & 242.2 & 8.2 & 9.0 & 16.2 & 149.7 & 16.9 & 5.4 & 28.3 \\
\hline NC119 & 2.452 & 43.536 & $\mathrm{M}$ & 8 & 59.0 & 1.161 & 0.528 & 82.4 & 4.7 & 6.6 & 18.0 & 351.7 & 7.5 & 7.6 & 18.4 \\
\hline NC120 & 2.452 & 43.544 & G & 5 & 41.1 & 1.046 & -0.100 & 235.9 & 17.4 & 6.3 & 34.0 & 10.2 & 65.8 & 15.8 & 36.4 \\
\hline NC121 & 2.455 & 43.555 & $\mathrm{M}$ & 5 & 60.5 & 1.046 & -0.043 & 9.0 & 49.6 & 4.6 & 6.8 & 167.8 & 38.4 & 5.6 & 34.6 \\
\hline NC122 & 2.467 & 43.564 & $\mathrm{M}$ & 7 & 273.0 & 1.100 & 0.245 & 248.1 & 12.5 & 9.5 & 24.4 & 144.9 & 45.8 & 15.2 & 29.3 \\
\hline NC123 & 2.494 & 43.594 & GM & 9 & 35.5 & 1.122 & 0.339 & 198.7 & 12.2 & 5.6 & 15.4 & 71.2 & 70.5 & 5.5 & 6.0 \\
\hline NC124 & 2.561 & 43.548 & $\mathrm{M}$ & 8 & 118.0 & 1.077 & 0.089 & 216.4 & 73.2 & 10.0 & 15.9 & 357.6 & 13.2 & 13.5 & 30.5 \\
\hline NC125 & 2.551 & 43.536 & G & 8 & 63.8 & 1.054 & 0.222 & 95.2 & 5.2 & 13.5 & 37.9 & 188.6 & 33.0 & 12.2 & 20.1 \\
\hline NC126 & 2.557 & 43.533 & M & 6 & 80.5 & 1.129 & 0.610 & 74.7 & 56.9 & 4.0 & 15.0 & 342.1 & 1.7 & 4.2 & 5.9 \\
\hline NC127 & 2.563 & 43.542 & M & 6 & 211.0 & 1.118 & 0.611 & 34.0 & 73.5 & 13.7 & 43.8 & 149.4 & 7.2 & 12.5 & 19.4 \\
\hline NC128 & 2.597 & 43.546 & $\mathrm{M}$ & 7 & 31.7 & 1.070 & 0.422 & 278.7 & 61.6 & 8.6 & 18.7 & 155.8 & 16.4 & 7.8 & 29.7 \\
\hline NC129 & 2.683 & 43.589 & $\mathrm{G} / \mathrm{M}$ & 6 & 178.0 & 1.027 & 0.408 & 197.2 & 24.5 & 3.4 & 27.2 & 89.0 & 34.4 & 18.6 & 22.8 \\
\hline NC130 & 2.689 & 43.587 & $\mathrm{M} / \mathrm{CB}$ & 10 & 625.0 & 1.364 & 0.183 & 60.9 & 13.2 & 14.5 & 27.0 & 152.6 & 7.1 & 7.4 & 22.1 \\
\hline NC131 & 2.692 & 43.582 & M & 5 & 190.0 & 1.198 & 0.768 & 56.2 & 7.7 & 12.7 & 24.1 & 147.7 & 10.9 & 6.0 & 19.1 \\
\hline NC132 & 2.660 & 43.534 & GS & 7 & 46.0 & 1.079 & 0.200 & 243.0 & 13.3 & 10.1 & 20.1 & 147.2 & 23.3 & 18.1 & 25.2 \\
\hline NC133 & 2.455 & 43.529 & $\mathrm{M}$ & 9 & 69.8 & 1.066 & -0.307 & 268.1 & 15.6 & 14.7 & 23.9 & 2.9 & 16.8 & 13.2 & 49.7 \\
\hline NC134 & 2.633 & 43.685 & GM & 5 & 61.0 & 1.140 & 0.720 & 22.3 & 22.1 & 3.7 & 17.5 & 167.3 & 63.2 & 2.5 & 8.1 \\
\hline NC135 & 2.734 & 43.682 & GM & 6 & 69.6 & 1.138 & 0.556 & 48.6 & 27.5 & 1.5 & 40.3 & 272.4 & 54.5 & 4.1 & 8.5 \\
\hline
\end{tabular}

Table 1 
